bioRxiv preprint doi: https://doi.org/10.1101/2021.12.05.471303; this version posted December 7, 2021. The copyright holder for this preprint (which was not certified by peer review) is the author/funder, who has granted bioRxiv a license to display the preprint in perpetuity. It is made available under aCC-BY-NC-ND 4.0 International license.

\title{
Subcellular spatial transcriptomics identifies three mechanistically different classes of
}

\section{localizing RNAs}

Lucia Cassella ${ }^{1,2}$ and Anne Ephrussi ${ }^{1 *}$

${ }^{1}$ European Molecular Biology Laboratory, Meyerhofstrasse 1, Heidelberg, 69117, Germany

${ }^{2}$ Collaboration for joint $\mathrm{PhD}$ degree between EMBL and Heidelberg University, Faculty of Biosciences

*corresponding author, anne.ephrussi@embl.org 


\section{Abstract}

2 Intracellular RNA localization is a widespread and dynamic phenomenon that compartmentalizes gene

3 expression and contributes to the functional polarization of cells. Thus far, mechanisms of RNA

4 localization identified in Drosophila have been based on a few RNAs in different tissues, and a

5 comprehensive mechanistic analysis of RNA localization in a single tissue is lacking. Here, by

6 subcellular spatial transcriptomics we identify RNAs localized in the apical and basal domains of the

7 columnar follicular epithelium (FE) and we analyze the mechanisms mediating their localization.

8 Whereas the dynein/BicD/Egl machinery controls apical RNA localization, basally-targeted RNAs

9 require kinesin-1 to overcome a "default" dynein-mediated transport. Moreover, a non-canonical,

10 translation- and dynein-dependent mechanism mediates apical localization of a subgroup of dynein-

11 activating adaptor RNAs (BicD, Bsg25D, hook). Altogether, our study identifies at least three

12 mechanisms underlying RNA localization in the FE, and suggests a possible link between RNA localization and dynein/dynactin/adaptor complex formation in vivo. 


\section{INTRODUCTION}

RNA localization allows the precise compartmentalization of gene expression in space and time, and is a widespread phenomenon in many different cell types and organisms (Shepard et al., 2003; Blower et al., 2007; Lécuyer et al., 2007; Mili et al., 2008; Jambor et al., 2015; Wilk et al., 2016; Moor et al., 2017). Three main mechanisms have been described to account for RNA localization: (1) active transport on cytoskeletal tracks, (2) localized protection from degradation, or (3) facilitated diffusion and entrapment (Medioni et al., 2012). Recently, several novel mechanisms have been reported to mediate RNA localization, such as hitch-hiking on other RNAs or organelles and cotranslational RNA transport (Corradi et al., 2020; Cioni et al., 2019; Liao et al., 2019; Baumann et al., 2014; Harbauer et al., 2021; Cohen et al., 2021; Sepulveda et al, 2018). Active transport is the best characterized mode of RNA localization and consists in the transport of ribonucleoprotein particles by motor proteins on cytoskeletal tracks. Localizing RNAs are typically transported in a translationally silent state and encode cis-acting localization elements (LEs) that are recognized and bound by transacting RNA-binding proteins (RBPs) mediating motor recruitment (Xing \& Bassell, 2013).

Kinesin motor proteins mostly mediate microtubule (MT) plus end-directed transport. Kinesin-1 (Khc) has been shown to mediate oskar (osk) RNA localization to the posterior pole of the Drosophila oocyte (Brendza et al., 2000; Zimyanin et al., 2008). Whereas Tropomyosin-1 isoform I/C (atypical Tm1, aTm1) regulates osk posterior localization by directly stabilizing Khc interaction with the RNA (Dimitrova-Paternoga et al., 2021; Gáspár et al., 2016; Erdélyi et al., 1995), the Exon Junction Complex (EJC) deposited upon splicing is thought to activate kinesin-1 transport of the RNA (Gáspár et al., 2016). Little is known about MT plus end-directed RNA transport in other tissues. Interestingly, aTm1 is also important for coracle RNA localization at Drosophila neuromuscular junctions (Gardiol \& St Johnston, 2014) and the EJC has been shown to mediate NIN RNA localization in human RPE1 cells (Kwon et al., 2021).

Cytoplasmic dynein and its accessory complex dynactin direct trafficking of cargoes towards MT minus ends. In Drosophila, dynein-mediated RNA transport is accomplished by the dynein-activating adaptor Bicaudal-D (BicD) and the RNA binding protein Egalitarian (Egl) (Mach \& Lehmann, 1997; Navarro et al., 2004; Dienstbier et al., 2009). The dynein/BicD/Egl complex is thought to mediate 
bioRxiv preprint doi: https://doi.org/10.1101/2021.12.05.471303; this version posted December 7, 2021. The copyright holder for this preprint (which was not certified by peer review) is the author/funder, who has granted bioRxiv a license to display the preprint in perpetuity. It is made available under aCC-BY-NC-ND 4.0 International license.

nurse cell-to-oocyte transport of maternal RNAs, and was shown to direct apical RNA localization in the early embryo, neuroblasts, and polar cells (Clark et al., 2007; Wilkie \& Davis, 2001; Bullock \& IshHorowicz, 2001; Hughes et al., 2004; Van De Bor et al., 2011). The dynein/dynactin/BicD (DDB) motor complex is highly conserved and participates in the transport of different cargoes, with BicD (and its mammalian ortholog BICD2) linking the dynein motor to specific cargoes. While proteins binding to the BicD C-terminal domain (CTD), such as Egl or Rab6, impart cargo specificity (Matanis et al., 2002; Hoogenraad et al., 2003; Dienstbier et al., 2009; Coutelis \& Ephrussi 2007; Januschke et al., 2007), the BicD N-terminal domain (corresponding to coiled-coil 1/2, CC1/2) binds to dynein/dynactin (Hoogenraad et al., 2001, 2003) and activates dynein processivity (McKenney et al., 2014; Schlager et al., 2014; Dienstbier et al., 2009; Sladewski et al., 2018).

Although much of what is known about RNA localization comes from studies of maternally inherited RNAs in the Drosophila germline, several examples of localizing RNAs have been also reported in the follicular epithelium (FE) that envelops the germline cyst (Jambor et al., 2015; Li et al., 2008; HorneBadovinac \& Bilder, 2008; Vazquez-Pianzola et al., 2017; Schotman et al., 2008; Serano \& Rubin, 2003). The FE is composed of highly polarized secretory follicle cells (FCs) belonging to the somatic lineage, with minus ends of non-centrosomal microtubules (ncMTs) anchored at the apical cell cortex facing the oocyte (Clark et al., 1997; Khanal et al., 2016). The FE is an easily manipulatable and powerful genetic system that, through the generation of mosaics, allows the dissection of the effect of mutations without disrupting developmental processes. Several lines of evidence indicate that the dynein/BicD/Egl RNA transport complex active in nurse cell-to-oocyte transport is also responsible for the apical localization of a handful of RNAs in the FE (Li et al., 2008; Bhagavatula \& Knust, 2021; Karlin-McGinness et al., 1996; Jambor et al., 2014; Vazquez-Pianzola et al., 2017; Van De Bor et al., 2011). However, a comprehensive overview of RNA localization in the FE and its underlying mechanisms are lacking.

Here, we apply subcellular spatial transcriptomics to first identify the landscape of apically- and basally-localizing RNAs in the columnar FE. By screening a subset of apical and basal RNAs identified in this way, we find that the dynein/BicD/Egl machinery acts by "default" in directing apical RNA localization, and that an additional kinesin-1-dependent layer of regulation must be applied to direct 
bioRxiv preprint doi: https://doi.org/10.1101/2021.12.05.471303; this version posted December 7, 2021. The copyright holder for this preprint (which was not certified by peer review) is the author/funder, who has granted bioRxiv a license to display the preprint in perpetuity. It is made available under aCC-BY-NC-ND 4.0 International license.

75 basal RNA localization. Moreover, we identify a third, translation- and dynein-dependent mechanism

76 that underlies the apical localization of transcripts encoding dynein-activating adaptors, providing a

77 possible link between RNA localization and dynein/dynactin/adaptor complex formation in vivo. 


\section{RESULTS}

Identification of apical and basal RNAs in columnar follicle cells

To identify RNAs that localize apically or basally in Drosophila FE transcriptome-wide, we applied laser-capture microdissection (LCM) to isolate fragments of tissue that consisted in either the apical half ("apical domain") or basal half ("basal domain") of adjacent columnar follicle cells (Figure 1A and Movie S1). Differential gene expression analysis of apical vs. basal LCM-derived RNA-seq samples yielded 306 RNAs enriched in the apical samples and 249 RNAs enriched in the basal samples (false discovery rate $[F D R]<0.1)($ Figure 1B). Since LCM is highly susceptible to tissue contamination, we first aimed at identifying those RNAs whose significant enrichment was a result of contamination by other cell types, such as the oocyte on the apical side or the circular muscles on the basal side (Figure S1A). To do so, we analyzed those RNAs characterized by high absolute log2-transformed fold change (|log2FC|) values of apical over basal abundance that might result from contamination of neighboring tissues expressing a different set of hallmark genes. By setting an arbitrary threshold of $|\log 2 \mathrm{FC}|>3$ as indicative of contaminant RNA identity, we found 33 putative basal contaminants of muscle origin ( $\log 2 \mathrm{FC}<-3$ ) and 2 putative apical contaminants of oocyte origin (log2FC $>3$ ) (Figure 1B and Figure S1B). 2/3 ( $n=22)$ of basal genes with log2FC $<-3$ were annotated as being expressed or having a function in muscle tissues (FlyBase) and their mapped reads were often absent or in very low number in the apical fragments (Figure S1C,D). Moreover, we validated through single molecule Fluorescence In Situ Hybridization (smFISH) 3 putative basal contaminants (Mhc, Act57B, wupA) as being enriched in circular muscles with little or no expression in the FE (Figure S1E). This analysis resulted in 304 bona fide apical RNAs and 216 bona fide basal RNAs localizing in the columnar FE (Figure 1B, Table S1). Finally, 16 RNAs were randomly chosen from the computationally established list of significantly enriched bona fide apical or basal RNAs and were validated as true localizing RNAs through smFISH (Figure 1C).

\section{Basal RNA localization depends on kinesin-1, aTm1, and the EJC}

106 Basal RNA localization is a largely uncharacterized phenomenon. Previous reports have identified a 107 limited number of basally-localizing RNAs in the FE (Jambor et al., 2015; Schotman et al., 2008; 108 Serano \& Rubin, 2003), with little mechanistic insight. For this reason, we sought to elucidate the 
bioRxiv preprint doi: https://doi.org/10.1101/2021.12.05.471303; this version posted December 7,2021 . The copyright holder for this preprint (which was not certified by peer review) is the author/funder, who has granted bioRxiv a license to display the preprint in perpetuity. It is made available under aCC-BY-NC-ND 4.0 International license.

mechanisms behind basal RNA localization. Early reporter-based studies on the polarity of Drosophila tissues have shown that the basal domain of the FE is functionally equivalent to the posterior pole of

111 the oocyte, as both compartments accumulate the MT plus end marker Kin:ßgal (Clark et al., 1997).

112 Therefore, we hypothesized that the regulators of oskar posterior RNA transport might also be

113 responsible for basal RNA localization in the FE. To test this hypothesis, we disrupted known

114 components of the osk RNP transport machinery, such as kinesin-1 (Khc), atypical Tropomyosin-1

115 (aTm1) and the Exon Junction Complex (EJC) (Figure S2A) in the FE and analyzed the localization 116 pattern of 4 validated basal RNAs (Fkbp14, CG3308, Rtn/1, zip) (Figure 2). In all cells lacking either

117 Khc (Khc RNAi cells) (Figure 2A), aTm1 (Tm1 ${ }^{\text {NULL }}$, Erdélyi et al., 1995) (Figure 2B), or the EJC ( $\Delta C$ -

118 Pym cells, Ghosh et al., 2014) (Figure 2C), basal RNA localization was severely disrupted, with all

119 basal RNAs analyzed becoming apically localized. To check whether the changes observed in RNA

120 localization were specific of basal RNAs, we analyzed the localization pattern of 4 apical RNAs

121 validated previously (crb, $m s p s$, qtc, CG33129) in the same mutants. In contrast to basal RNAs, none

122 of the apical RNAs analyzed were affected by disruption of kinesin-1-mediated RNA transport (Figure

123 S2B-D), indicating that regulators of RNA transport towards MT plus ends specifically control basal

124 RNA localization. To have a quantitative overview of changes in RNA localization, we considered the

125 ratio between the apical and the basal smFISH signal intensity in either wild-type (wt) or knock-down

$126(\mathrm{KD})$ cells, and called this parameter Degree of Apicality $(\mathrm{DoA})$, as values $>1$ indicate an apical

127 localization bias. Then, we tested whether the DoA values of each RNA analyzed significantly differ in

$128 \mathrm{KD}$ vs. wt cells by calculating the ratio between the DoA(KD) and the DoA(wt) for each RNA in each of

129 the 3 conditions (see Materials and Methods and Figure 2 for statistical testing). With this analysis, we

130 confirmed that (1) all basal RNAs were affected by lack of Khc, aTm1, or EJC and (2) none of the

131 apical RNAs significantly changed localization pattern upon knock-down of kinesin-1 regulators

132 (Figure 2D), showing that kinesin-1, aTm1, and the EJC are specifically responsible for basal RNA

133 localization in the FE.

\section{Mislocalization of the basal RNA zip depends on Egalitarian}

136 Interestingly, upon disruption of MT plus end-directed RNA transport all analyzed basal RNAs were

137 mislocalized to the apical domain. Several studies reported that apical RNA localization depends on 138 the BicD/Egl machinery, a dynein-dependent complex that localizes RNAs apically in the blastoderm 
bioRxiv preprint doi: https://doi.org/10.1101/2021.12.05.471303; this version posted December 7,2021 . The copyright holder for this preprint (which was not certified by peer review) is the author/funder, who has granted bioRxiv a license to display the preprint in perpetuity. It is made available under aCC-BY-NC-ND 4.0 International license.

139 embryo and is thought to be responsible for nurse cell-to-oocyte transport of maternal RNAs.

140 Therefore, the apical mislocalization of basal RNAs observed upon knock-down of kinesin-1 regulators

141 might be due to apical RNA transport by the dynein/BicD/Egl machinery. To test this, we generated FC

142 clones lacking either Egl (egl RNAi) or Khc (Khc RNAi), or both Egl and Khc [(egl+Khc) RNAi] and

143 evaluated changes in the RNA localization of zip, one of the most striking examples of the apical

144 mislocalization phenomenon (see Figure 2A-C). Whereas zip RNA was unaffected upon egl RNAi and

145 strongly apically mislocalized in Khc RNAi conditions as also highlighted by our previous experiments,

$146($ egl+Khc) RNAi caused zip to assume a ubiquitous localization that would be consistent with a failure

147 of both kinesin-1-and dynein-mediated transport (Figure S3A). zip DoA measurements in wt and RNAi

148 cells in each of the three conditions provided a quantitative evaluation of the changes observed in

149 smFISH experiments (Figure S3B), with a significant decrease in KD/wt DoA in double (egl+Khc)

150 RNAi cells $(K D / w t$ DoA $=1.61)$ compared to $K h c$ RNAi cells $(K D / w t$ DoA $=2.49)$ (Figure S3C).

151 Therefore, despite being dispensable in basal RNA localization under normal conditions, the

152 dynein/BicD/Egl complex is responsible for the apical mislocalization of a basal RNA (and possibly

153 more) when kinesin-1 activity is lacking.

155 Two different dynein-dependent mechanisms control apical RNA localization

156 As mentioned previously, several reports have identified the dynein/BicD/Egl machinery as

157 responsible for the apical localization of a subset of RNAs in the FE, such as crumbs (crb) (Li et al.,

158 2008; Bhagavatula \& Knust, 2021). To test in an unbiased way the degree of involvement of the

159 dynein/BicD/Egl machinery in the localization of apical RNAs in the FE, we generated FC mutant

160 clones in which either cytoplasmic dynein (Dhc64C, hereafter called Dhc) or Egalitarian (egl) were

161 knocked-down by RNAi (Figure S4A). We then analyzed the localization pattern of 5 validated apical

162 RNAs (crb, msps, qtc, CG33129, BicD, with crb RNA as a positive control) by smFISH, along with the

163 quantification of RNA localization by measuring the KD/wt DoA. The localization of all apical RNAs

164 analyzed was completely abolished when Dhc was knocked down by RNAi, with the RNAs becoming

165 ubiquitously distributed (Figure 3A,C). eg/ RNAi caused all apical RNAs to lose their apical

166 localization, with the surprising exception of BicD (Figure 3B,C; see below). In contrast, basal RNAs

167 largely maintained their basal localization pattern upon either Dhc RNAi or egl RNAi treatment (Figure

168 S4B,C and Figure 3C). Basal RNA localization was only mildly affected in a subset of Dhc RNAi cells, 
bioRxiv preprint doi: https://doi.org/10.1101/2021.12.05.471303; this version posted December 7,2021 . The copyright holder for this preprint (which was not certified by peer review) is the author/funder, who has granted bioRxiv a license to display the preprint in perpetuity. It is made available under aCC-BY-NC-ND 4.0 International license.

169 likely as a consequence of the emergence of polarity defects in cells lacking Dhc (Horne-Badovinac \& 170 Bilder, 2008; Ronchi et al, 2021) (see Figure 3A and Figure S3B). The maintenance of BicD RNA 171 localization in egl RNAi cells was not due to a low efficiency of the RNAi, since both egl RNA and Egl 172 protein were significantly reduced in egl KD cells (Figure S4D,E). Moreover, in egg chambers entirely 173 lacking Egl throughout the FE (eg/NULL $F C$, see Materials and Methods), BicD RNA was still apically 174 localized, whereas localization of CG33129 RNA, previously found to be Egl-dependent (see Figure 175 3B), was disrupted (Figure S4F). Altogether, these results show that the dynein/BicD/Egl complex is 176 largely responsible for apical RNA localization, but a different dynein-dependent mechanism underlies 177 the apical localization of BicD RNA. Considering that the Egl-independent targeting of BicD RNA represents a novel mechanism of apical RNA localization, we sought to gain more insight into the

179 mechanisms regulating its RNA transport.

\section{BicD RNA localization requires an intact translation machinery} Localization of $B I C D 2 / B i c D$ RNA at centrosomes in cultured cells is translation-dependent (Safieddine et al., 2021). To test whether BicD RNA localization in the FE involves the same mechanism, we treated egg chambers ex vivo with the translation inhibitors puromycin (Puro) and cycloheximide (CHX) and analyzed the distribution of BicD RNA under these two conditions compared to control ovaries incubated in Schneider's medium only (Figure 4A). To assess tissue integrity, in parallel we

187 visualized osk RNA, whose localization during the middle stages of oogenesis should not be affected by translation inhibitors. Whereas the localization pattern of BicD RNA in CHX-treated egg chambers was similar to controls (Figure 4B,D), Puro treatment clearly impaired BicD RNA localization in the FE

190 (Figure 4C). The distribution of BicD signal intensity along the A-B axis of mid-stage follicle cells 191 shows that BicD enrichment at the apical cortex of the FE was severely reduced upon Puro treatment

192 (Figure 4E). As a proxy for the degree of signal mislocalization, we calculated the value

193 corresponding to $50 \%$ of the cumulative area under the curve (a.u.c.) in Puro- or CHX-treated egg 194 chambers and compared it with untreated controls. The results of this analysis show that the BicD 195 RNA signal shifted significantly towards the basal domain in Puro-treated egg chambers, whereas

$196 \mathrm{CHX}$ had no effect on BicD RNA localization (Figure 4F). The fact that freezing elongating ribosomes 197 (CHX condition) does not affect BicD RNA localization, whereas blocking translation by releasing the 
bioRxiv preprint doi: https://doi.org/10.1101/2021.12.05.471303; this version posted December 7, 2021. The copyright holder for this preprint (which was not certified by peer review) is the author/funder, who has granted bioRxiv a license to display the preprint in perpetuity. It is made available under aCC-BY-NC-ND 4.0 International license.

nascent peptide (Puro condition) does, indicates that an intact translation machinery and the presence of a nascent peptide may be required for BicD RNA localization in FCs.

\section{BicD RNA is co-translationally localized}

202 To understand whether the localization of BicD depends on translation of its own RNA (in cis) or of other factors (in trans), we designed a series of transgenic constructs consisting of a BicD-GFP cassette inserted downstream of an 18-bp linker in which we could introduce the desired frameshift mutations without disrupting any unknown RNA localization element in the BicD CDS (Figure S5A). Each of these transgenes was expressed in FC clones in a BicD wild-type background and the transgenic BicD-GFP RNA was specifically detected by smFISH using antisense GFP probes. GFP RNA carrying the same 3' untranslated region (UTR) as BicD-GFP constructs failed to localize when expressed in the germline or in the FE (Figure S5B), showing that this sequence alone is not

210 sufficient to drive RNA localization. In contrast, the in-frame ${ }^{\circ} B i c D$-GFP RNA showed a strong apical 211 localization in FCs (Figure 4G-I), similarly to the endogenous BicD RNA (see Figure S6A). Moreover,

212 the expression of full-length BicD-GFP was validated by the presence of GFP fluorescence in CD8-

$213 \mathrm{mCherry}^{+}$cells expressing the transgene (Figure 4G). Disruption of the BicD-GFP reading frame by

214 either +1 or -1 frameshift, verified by the absence of GFP signal in CD8-mCherry ${ }^{+}$cells, was sufficient

215 to impair apical RNA localization (Figure 4G-I). Consistent with the puromycin-induced impairment of

216 RNA localization in the FE, these results show that BicD RNA is co-translationally localized at the

217 apical cortex.

\section{BicD and Dhc RNAs decorate dynein particles at the apical cortex}

220 As in BicD the first peptide emerging from the ribosome is the dynein-binding domain (Hoogenraad et al., 2003), the co-translational localization of BicD RNA might depend on association of nascent BicD

222 protein with dynein. To have an indication whether this might be the case, we imaged BicD RNA by smFISH in ovaries expressing endogenously tagged Dhc-GFP (Gaspar et al., 2021). Although the

224 Dhc-GFP signal was diffuse in the ovary, distinct Dhc-GFP foci were detected at the apical cortex of 225 columnar FCs (Figure 4J) and elsewhere in the germline (see below). These foci also contain Dhc 226 RNA, indicating that these might be sites of Dhc RNA translation. BicD RNA showed a partial co- 
bioRxiv preprint doi: https://doi.org/10.1101/2021.12.05.471303; this version posted December 7,2021 . The copyright holder for this preprint (which was not certified by peer review) is the author/funder, who has granted bioRxiv a license to display the preprint in perpetuity. It is made available under aCC-BY-NC-ND 4.0 International license.

227 localization with Dhc-GFP/Dhc RNA foci, consistent with the hypothesis of its co-translational association with newly synthesized Dhc protein at the apical cortex.

The first step of BicD RNA localization in the early cyst is translation-independent

231 In the germline, BicD has an instructive role in oocyte specification (Wharton \& Struhl, 1989; Suter \&

232 Steward, 1991; Mach \& Lehmann, 1997). Importantly, BicD RNA localization reflects MT minus end

233 enrichment (Steinhauer \& Kalderon, 2006; Clark et al., 1997) in both the germline and FE (Figure

234 S6A). We noticed that, as in the FE, BicD RNA localization to the posterior of the oocyte (stages 9-10)

235 was impaired in Puro-treated ovaries, whereas CHX had no effect (Figure 4C,D). The same effect

236 was visible in younger egg chambers, starting when BicD becomes posteriorly localized in the small

237 oocyte at stages 4-5 (Figure S6B). In contrast, neither Puro nor CHX treatment abolished BicD nurse

238 cell-to-oocyte transport in early egg chambers, with BicD enrichment in the small oocyte being close to

239 wild-type levels (Figure S6B). Consistent with this, germline-driven Frameshift BicD-GFP RNA

240 underwent nurse cell-to-oocyte transport and displayed a clear oocyte enrichment during early stages,

241 similarly to endogenous BicD (Figure S6C). However, within the oocyte, Frameshift RNA was

242 ubiquitously distributed at these stages, and failed to localize at the posterior cortex of the small

243 oocyte. These results indicate that the process of BicD RNA transport into the oocyte does not involve

244 active translation; on the other hand, BicD RNA localization within the oocyte is likely governed by the

245 same co-translational mechanism that operates in the FE. In support of this hypothesis, we found that

246 BicD RNA decorates Dhc/Dhc RNA foci in both the FE and the oocyte, but not in the nurse cells

247 (Figure S6D). Taken together, these results indicate that the mid-oogenesis oocyte and the columnar

248 FCs share a similar co-translational mechanism for BicD RNA localization. In contrast, BicD RNA

249 nurse cell-to-oocyte localization appears to be mediated by a translation-independent mechanism that 250 does not involve the association with Dhc/Dhc RNA particles.

252 A subset of dynein-activating adaptor RNAs are also co-translationally localized in the FE

253 BicD belongs to the class of dynein-activating adaptors, linking cargoes to the dynein motor complex

254 (Olenick \& Holzbaur, 2019). We found that the RNA encoding all Drosophila orthologs of the currently

255 known or putative dynein activating adaptors (hereafter collectively called "adaptor RNAs"), namely

256 hook (HOOK2-3), Bsg25D (NIN/NINL), Nuf (RAB11FIP3), and Milton (TRAK1-2), were significantly 
257 enriched apically in our list of localizing transcripts (Table S1), with the exception of Spindly (SPDL1)

258 which was below the detection threshold. By hypothesizing that the same dynein-dependent co-

259 translational process that drives BicD RNA localization would also be responsible for the apical

260 localization of adaptor RNAs, we tested whether the localization of adaptor RNAs was affected by

261 either Dhc or egl RNAi. With the exception of Nuf and Milton, whose localization was disrupted by

262 either treatment (data not shown), the apical localization of $B s g 25 D$ and hook (Figure 5A) was

263 significantly disrupted in Dhc RNAi cells (Figure 5B,D), but not in egl RNAi cells (Figure 5C,D).

264 Moreover, the apical localization of both adaptor RNAs showed sensitivity to Puro but not CHX

265 (Figure 5E,F), although the change measured in $B s g 25 D$ signal distribution along the A-B axis in the

266 FE was not significantly different from untreated control (Figure 5G). However, Bsg25D is expressed

267 at low levels in the FE, hindering a robust quantitative image analysis. To further investigate whether

268 hook and Bsg25D use the same localization mechanism as $B i c D$, we analyzed their spatial

269 relationship with Dhc-GFP/Dhc RNA particles. As for BicD, both Bsg25D (Figure 5H) and hook

270 (Figure 5I) were shown to partially co-localize with, thus decorate Dhc-GFP foci, which also contain

271 Dhc RNA. Overall, these results suggest that the RNAs encoding the dynein activating adaptors BicD,

272 hook, and Bsg25D, represent a subgroup of apical RNAs that share the same co-translational, dynein-

273 dependent mechanism that ensures their localization at cortical dynein foci also containing Dhc RNA. 
bioRxiv preprint doi: https://doi.org/10.1101/2021.12.05.471303; this version posted December 7,2021 . The copyright holder for this preprint (which was not certified by peer review) is the author/funder, who has granted bioRxiv a license to display the preprint in perpetuity. It is made available under aCC-BY-NC-ND 4.0 International license.

\section{DISCUSSION}

276 Only few examples of localizing RNAs in the FE have been described to date, with little mechanistic 277 insight (Jambor et al., 2015; Li et al., 2008; Horne-Badovinac \& Bilder, 2008; Vazquez-Pianzola et al., 278 2017; Schotman et al., 2008; Serano \& Rubin, 2003). To explore the extent of RNA localization in a 279 somatic tissue in vivo and gain insight into the mechanisms underlying the phenomenon, we have 280 used laser-capture microdissection of apical and basal subcellular fragments of columnar follicle cells 281 coupled with RNA-seq to identify localizing RNAs in this tissue. This allowed us to investigate in detail 282 the landscape of mechanisms that mediate both apical and basal RNA localization in the FE (Figure 283 6A). In our study, we found that basal RNA localization is mechanistically analogous to posterior RNA 284 localization in the oocyte (represented by osk), reflecting MT plus end enrichment (Clark et al., 1997). 285 Khc, aTm1, and the EJC appear to be core components of a general "basal" RNA localization machinery. These results are in line with previous findings on osk RNA indicating that Khc/aTm1 bind 287 to the 3'UTR (Gaspar et al., 2017) and the EJC activates kinesin-1 transport through association with 288 the coding sequence (Ghosh et al., 2012). Interestingly, when either component of the kinesin-1 transport complex was lacking, basal RNAs 291 were mislocalized to the apical domain in a dynein-dependent process. Therefore, dynein-mediated apical localization represents a "default" mechanism that must be overcome by kinesin-1 to drive basal RNA localization. Two possible scenarios could explain dynein-mediated apical mislocalization upon

294 kinesin inhibition. Dynein and kinesin-1 could be engaged in a tug of war, pulling the RNAs in 295 opposing directions, a phenomenon observed in the transport of vesicles and lipid droplets (Hancock, 296 2014). Alternatively, the dynein complex could be kept in an inhibited state and activated upon 297 disruption of kinesin-1 and its regulators. If the tug-of-war scenario were correct, we would have 298 expected a change in zip RNA localization in all RNAi conditions including eg/ RNAi alone, namely a 299 shift to a more basal localization due to the enhanced Khc-dependent motility. However, since we did 300 not see a significant change in zip localization when only Egl was knocked down, the tug-of-war 301 hypothesis appears to be less likely than the inhibition hypothesis. In addition, this phenomenon 302 recalls osk RNA mislocalization to the oocyte anterior upon disruption of kinesin-1, aTm1 or EJC 303 components (Brendza et al., 2000; Cha et al., 2002; Erdélyi et al., 1995; Hachet \& Ephrussi, 2001; 304 Mohr et al., 2001; Newmark \& Boswell, 1994; Palacios et al., 2004; Zimyanin et al., 2008) which was 
305 hypothesized to occur due to a failure to inactivate dynein-mediated RNA transport (Zimyanin et al.,

306 2008).

Apical RNA localization, on the other hand, can be divided into two mechanistically distinct categories, both based on dynein-mediated transport. The first category includes those RNAs that are transported apically by the dynein/BicD/Egl machinery, a well characterized RNA transport complex that directs RNAs towards MT minus ends in a variety of tissues (Bullock \& Ish-Horowicz, 2001). Our data suggest that the majority of apically localizing RNAs may belong to this class, as the localization of most of our randomly chosen apical RNAs was affected in both Dhc RNAi and egl RNAi conditions. This hypothesis is consistent with previous studies that identified several apical RNAs as BicD/Egl cargoes, in a variety of Drosophila tissues (Li et al., 2008; Bhagavatula \& Knust, 2021; Karlin-McGinness et al., 1996; Jambor et al., 2014; Vazquez-Pianzola et al., 2017; Van De Bor et al., 2011).

318 The second category of dynein-dependent apical RNAs does not involve Egalitarian activity for their 319 localization. This includes a subgroup of dynein-activating adaptors, namely BicD, hook, and Bsg25D (BICD2, HOOK1-3, and NIN/NINL in mammals). Common features of their apical RNA localization

321 include sensitivity to puromycin and partial co-localization with cortical dynein foci containing also Dhc

322 RNA. Puromycin causes the disassembly of the translational machinery and the release of the N-

323 terminal peptides emerging from ribosomes. As the $\mathrm{N}$-terminal portion of these adaptors was shown to 324 bind dynein or dynactin subunits (Hoogenraad et al., 2003; Chowdhury et al., 2015; Urnavicius et al., 325 2015; Schroeder \& Vale, 2016; Redwine et al., 2017; Lee et al., 2020), we propose that the apical localization of $B i c D$, hook, and $B s g 25 D$ depends on the co-translational association between dynein

327 components and nascent adaptors at cortical dynein foci (Figure 6B). This process might also be 328 conserved in mammals, since the localization of both BICD2 and NIN RNA was shown to be 329 puromycin-sensitive (Safieddine et al., 2021). Previous studies have shown that dynein/dynactin 330 particles have a low affinity to MTs and predominantly exhibit non-processive movements (Torisawa et 331 al., 2014; Trokter et al., 2012). BICD2, HOOK3 and NIN/NINL were shown to promote the formation of 332 highly processive dynein/dynactin complexes (McKenney et al., 2014; Schalager et al., 2014; Redwine 333 et al., 2017). Therefore, it is possible that co-translational assembly of components of the dyneinadaptor complexes is necessary to overcome dynein auto-inhibition (Torisawa et al., 2014; Zhang et 
bioRxiv preprint doi: https://doi.org/10.1101/2021.12.05.471303; this version posted December 7,2021 . The copyright holder for this preprint (which was not certified by peer review) is the author/funder, who has granted bioRxiv a license to display the preprint in perpetuity. It is made available under aCC-BY-NC-ND 4.0 International license.

al., 2017). BicD, hook, and Bsg25D may co-translationally associate with dynein soon after nuclear export of the RNA, promoting its apical transport in a manner similar to what has been proposed for PCNT RNA targeting at centrosomes (Sepulveda et al., 2018). Alternatively, since dynein can also function as a MT-tethered static anchor in mid-oogenesis oocytes and follicle cells (Delanoue \& Davis, 2005; Delanoue et al., 2007), the interaction between dynein and nascent adaptor proteins could occur after the RNA has reached the cell cortex by dynein-mediated transport. Indeed, puromycin treatment did not completely abolish the apical enrichment of adaptor RNAs, despite causing a marked decrease in their signal close to the apical cortex, where they decorate dynein cortical foci.

344 In vitro studies have shown that full-length BicD/BICD2 adopts an autoinhibitory conformation resulting 345 from CC1/2 folding onto the CTD-containing CC3 (Hoogenraad et al., 2001; Dienstbier et al., 2009; 346 Stuurman et al., 1999). Although the leading hypothesis in the field is that cargo binding to the CTD is 347 responsible for the alleviation of auto-inhibition by freeing up the $\mathrm{N}$-terminal dynein-binding domain 348 (Dienstbier et al., 2009; Hoogenraad et al., 2001, 2003; Matanis et al., 2002), it is possible that in vivo 349 both nascent BicD interaction with dynein and cargo binding to the CTD might cooperate in preventing 350 BicD intramolecular inhibition in the cellular environment. Strikingly, whereas the mechanism 351 underlying oocyte localization of BicD RNA during mid-oogenesis resembles that observed in follicle 352 cells, the nurse cell-to-oocyte transport of BicD RNA appears to be governed by a different,

353 translation-independent mechanism that may not involve interaction with Dhc/Dhc RNA particles, 354 consistent with a previous study indicating that BicD RNA is translationally inhibited by Me31B in the 355 nurse cells (Nakamura et al., 2001). In contrast to early egg chambers in which the MT network 356 emanates from a posteriorly-positioned microtubule organizing center in the oocyte, mid-stage oocytes 357 and columnar follicle cells are both characterized by non-centrosomal MTs tethered to the cell cortex 358 (Tillery et al., 2018). Therefore, the establishment of ncMTs could be at the basis of the mechanistic 359 switch from translation-independent to co-translational BicD RNA localization in these compartments. 360 Strikingly, a recent report has shown that NIN RNA (the mammalian ortholog of Bsg25D) localizes at 361 ncMTs and its expression is essential for apico-basal MT formation and columnar epithelial shape 362 (Goldspink et al., 2017). Therefore, it is possible that the co-translational transport of adaptor RNAs 363 may be important for correct ncMT nucleation at the apical cortex of the follicular epithelium. 


\section{MATERIALS AND METHODS}

366 w1118 virgin females were kept with males for $24 \mathrm{~h}$ at $25^{\circ} \mathrm{C}$ on yeast-supplemented cornmeal food.

367 Ovaries were dissected in PBS, transferred to a cryomold and snap-frozen in cold 2-Methylbutane

368 after removal of excess PBS. Frozen ovaries were immediately covered with OCT cryoembedding compound (Sakura) and snap-frozen again. Before cryostat sectioning, each block was equilibrated at $-20^{\circ} \mathrm{C}$ for $1 \mathrm{~h} .10 \mu \mathrm{m}$ cryosections of OCT-embedded ovaries were carefully placed on a MembraneSlide NF 1.0 PEN (Zeiss), briefly thawed at RT and immediately fixed in $75 \%$ RNase-free

372 (RF) ethanol for $30 \mathrm{~s}$. Excess OCT was removed with ddH2O RF, and slides were stained in $100 \mu \mathrm{l}$ 373 Histogene staining solution (Arcturus) according to the manufacturer's instructions. Finally, sections 374 were dehydrated in increasing ethanol concentrations (75\%, 95\%, 100\%), and briefly air-dried before 375 LCM.

378 LCM was performed with a Zeiss PALM MicroBeam and visualized under a 63X objective. Sectioned mid-oogenesis egg chambers were staged according to morphological criteria. Once stage 9-10 egg

380 chambers had been identified, either the apical half ("apical fragment") or the basal half ("basal

381 fragment") of 5-10 contiguous columnar follicle cells was microdissected and collected into the cap of 382 an AdhesiveCap tube (Zeiss). 10 fragments of either apical or basal sample type from different egg 383 chambers were pooled for each replicate, with a total microdissected area of $\sim 3000-4000$

$384 \mu \mathrm{m}^{2} /$ replicate. LCM samples were processed according to Chen et al. (2017) to produce high-quality 385 Illumina sequencing libraries. Samples were multiplexed and simultaneously sequenced in a single 386 lane using the NextSeq500 system according to the manufacturer's instructions.

\section{RNA-seq analysis}

389 Pre-processing of demultiplexed raw reads was performed on EMBL's instance of Galaxy platform.

390 Read quality was checked after each processing step with FastQC (Andrews, 2010). Low-quality

391 bases and adapter sequences were trimmed from raw read with Trimmomatic (Bolger et al., 2014).

392 rRNA-filtered reads (SortMeRNA, Kopylova et al., 2012) were mapped against $D$. melanogaster

393 Release 6 (dm6) reference genome with STAR (Dobin et al., 2013). To control for RNA degradation 
394 that might have occurred during LCM, the normalized transcript coverage of the uniquely mapping reads was calculated with CollectRNAseqMetrics (part of Picard tools,

396 http://broadinstitute.github.io/picard/). Uniquely mapped reads were counted with featureCounts (Liao et al., 2014) and normalized with DESeq2 (Love et al., 2014). Differential gene expression analysis

398 was performed with DESeq2 by comparing the mean read counts of the Apical (4 replicates, A1-A4) and Basal (4 replicates, B1-B4) samples. Replicates A5 and B5 were excluded from further analysis due to their high degree of dissimilarity with replicates of the same sample type as shown by PCA and

401 Euclidean distance analysis, probably due to a high degree of contamination from neighboring tissues.

402 Statistical significance was set to an FDR-adjusted $p$ value $<0.1$ (Benjamini-Hochberg correction for multiple testing). The R package ComplexHeatmap (Gu et al., 2016) was used to generate the

404 heatmap in Figure 2B.

405

Identification of contaminant reads

407 Identification of contaminant RNAs was performed with R Studio. Among the RNAs that were

408 significantly enriched in either the apical $(\log 2 \mathrm{FC}>0)$ or the basal $(\log 2 \mathrm{FC}<0)$ domain, were considered "contaminants" those RNAs displaying high absolute log2FoldChange ( $|\log 2 \mathrm{FC}|)$,

410 indicating that they were probably originating from neighboring tissues. A threshold of $\log 2 \mathrm{FC}>3$ and $411 \log 2 \mathrm{FC}<-3$ was arbitrarily set to identify putative apical and basal contaminants, respectively. The

412 functional annotation of each contaminant candidate was retrieved on FlyBase (release FB2020_6)

413 (Larkin et al., 2021) and their read distribution among apical and basal replicates analyzed through

414 Integrative Genomics Viewer (IGV) (Robinson et al., 2011).

\section{Fly stocks and genetics}

417 All fly stocks were maintained at $18^{\circ} \mathrm{C}$ on standard fly food. For crosses, virgin females were mated

418 with w1118 males at $25^{\circ} \mathrm{C}$ on cornmeal food supplemented with yeast. Female offspring of the desired 419 genotype were incubated with $w 1118$ males on a yeast-supplemented medium for $24 \mathrm{~h}$ at $25^{\circ} \mathrm{C}$ to 420 stimulate the development of vitellogenic stage egg-chambers before ovary dissection.

421 The following stocks were obtained from the Bloomington Drosophila Stock Center (BDSC): w1118 422 (wild-type; \#3605), DhcRNAi (\#36698), egIRNAi (\#28969), KhcRNAi (\#35409), UAS-NLS-mCherry 423 (\#38425), osk-Gal4 (\#44242), VK33 (\#9750). Other stocks used were: HsFLP; arm>f+>Gal4; 
UAS-CD8-mCherry and tj-Ga/4/CyO (gifts of Juan Manuel Gomez Elliff), Tm1 1991/TM3Sb,Ser and Tm1eg9/TM3Sb, Ser (Erdélyi et al., 1995), Dhc64C-GFP (Gáspár et al., 2021), vasa-Gal4/TM3Sb (gift of Jean Rene Huynh), UAS- $\triangle$ C-Pym-GFP (Ghosh et al., 2014), UAS-Egl (Bullock et al., 2006), eg/WU50/SM1 and eg/PR29/SM6A (Mach \& Lehmann, 1997). Transgenic flies carrying UAS-GFP, UAS${ }^{\circ}$ BicD-GFP, UAS-(+1)BicD-GFP, and UAS-(-1)BicD-GFP were generated in this study by phiC31 integrase-mediated recombination using the VK33 line, which carries an attP site on the third 430 chromosome.

431 For the generation of eg/NULLFC flies, eg/WU50/CyO; osk-Gal4/TM3Ser were crossed with eg/PR29/CyO; 432 UAS-EgI/TM3Ser to generate eg/WU50/eglPR29; osk-Ga/4/UAS-Egl, expressing Egl only in the germline 433 lineage to rescue the formation of rudimentary ovaries. $t j-G a / 4$ and vasa-Gal4 drivers were used to 434 express UAS-containing transgenes in the whole follicular epithelium and in the germline, respectively. 435 To generate flies for FC mutant clone induction, male flies carrying a UAS-containing transgene were 436 crossed with hsFlp; arm>f+>Gal4; UAS-CD8-mCherry virgins, and F1 females were subjected to heat437 shock as described below.

438 To generate flies for induction of FC mutant clones in the experiment illustrated in Figure S3, HsFLP; arm>f+>Gal4/CyO; KhcRNAi/TM6B,Tb flies were crossed with +; UAS-NLS-mCherry/CyO; egIRNAi/TM3Ser. F1 Female flies the desired genotypes [egIRNAi/TM6B,Tb for the egI RNAi condition; KhcRNAi/TM3Ser for the Khc RNAi condition; egIRNAi/KhcRNAi for the (egl+Khc) RNAi condition] were collected and subjected to heat-shock as described below.

\section{Generation of follicle cell clones}

445 The UAS-Gal4 "flip-out" system was used to generate marked mutant clones in a wild-type 446 background (Struhl \& Basler, 1983; Pignoni \& Zipurski, 1997). Freshly eclosed females resulting from 447 each cross were collected and mated with w1118 males for $24 \mathrm{~h}$ at $25^{\circ} \mathrm{C}$ on food supplemented with 448 yeast. Flies were heat-shocked for $1 \mathrm{~h}$ in a water bath heated at $37^{\circ} \mathrm{C}$. According to Gonzales-Reyes \& 449 St Johnston (1998), heat-shocked females were kept for $39 \mathrm{~h}$ at $25^{\circ} \mathrm{C}$ with males on yeast before 450 dissection, thus allowing follicle cells that induced the expression of the transgene at stage $\sim 5$ to 451 develop into stage 10 follicle cells. 
454 Young w1118 female flies were incubated with males for $24 \mathrm{~h}$ at $25^{\circ} \mathrm{C}$ on fly food supplemented with

455 yeast. Ovaries were dissected in PBS and immediately incubated in Schneider's medium (Gibco)

456 supplemented with 15\% FBS (Gibco), 0.6X penicillin/streptomycin (Invitrogen), $200 \mu \mathrm{g} / \mathrm{ml}$ insulin

457 (Sigma). For translation inhibitor treatment, either $200 \mu \mathrm{g} / \mathrm{ml}$ puromycin (Gibco) or $200 \mu \mathrm{g} / \mathrm{ml}$

458 cycloheximide (Sigma) or no compound (control) was added fresh to the medium and ovaries were

459 incubated for $30 \mathrm{~min}$ at RT before fixation.

460

\section{Generation of BicD-GFP constructs and transgenic fly lines}

462 AttB-pUASp-BicD-GFP-K10 or AttB-pUASp-GFP-K10 plasmids carrying a $w+$ cassette, a TLS-

463 deficient version of the K10 3'UTR, and attB sites for phiC31 integrase-mediated recombination into

464 the VK33 line were generated as follows.

465 To generate plasmid vectors carrying the BicD-GFP gene cassettes $\left({ }^{\circ} B i c D-G F P,{ }^{(-1)} B i c D-G F P\right.$,

$\left.466{ }^{(+1)} B i c D-G F P, G F P\right), B i c D$ and GFP CDS were amplified by PCR and the two fragments were

467 combined into AttB-pUASp-K10 vector by InFusion cloning (Clontech) according to the manufacturer's

468 instructions. pBS-BicD (BicD-RA, FlyBase ID: FBpp0080555) plasmid (a kind gift from Jean-Baptiste

469 Coutelis) was used as template to generate BicD CDS PCR amplicons. The Fw primer used to amplify

470 BicD CDS was designed in order to include, in addition to a 20 nt-homology with AttB-pUASp-K10

471 vector, the Drosophila Kozak sequence (Cavener, 1987) in frame with a linker sequence where

472 frameshift mutations could be generated, and a region annealing to nt 4-29 of BicD CDS. To generate

$473{ }^{\circ}$ BicD-GFP construct, the 18-bp linker containing the ATG (5'- ATGATCCTAGGCGCGCGG- 3') was

474 inserted in frame with nt 4-2346 of BicD-RA. To generate ${ }^{(+1)} B i c D-G F P$ construct, a $C$ was inserted at

475 position 4 in the N-terminal 18-bp linker (5'- ATGCATCCTAGGCGCGCGG- 3'). To generate ${ }^{(-1)} B i c D$ -

476 GFP construct, a $\mathrm{G}$ was deleted at position 10 in the N-terminal 18-bp linker (5'-

477 ATGATCCTA_GCGCGCGG- $\left.3^{\prime}\right) .{ }^{\circ} B i c D-G F P,(-1) B i c D-G F P$, and ${ }^{(+1)} B i c D-G F P$ full insert sequences

478 with the respective predicted translated ORF are listed in File S2.

479 To generate UAS-GFP construct, GFP ORF was amplified with a Fw primer containing Kpnl restriction

480 site upstream of GFP ATG and with a Rev primer containing Notl restriction site and the stop codon.

481 The amplified fragment was gel purified, digested with Kpnl and Notl and ligated into a AttB-pUASp-

482 K10 vector digested with the same enzymes. 
bioRxiv preprint doi: https://doi.org/10.1101/2021.12.05.471303; this version posted December 7, 2021. The copyright holder for this preprint (which was not certified by peer review) is the author/funder, who has granted bioRxiv a license to display the preprint in perpetuity. It is made available under aCC-BY-NC-ND 4.0 International license.

483 Each AttB-containing plasmid was purified and sequenced before injection into VK33 embryos carrying an attP site on the $3^{\text {rd }}$ chromosome. Injected flies were crossed with If/CyO; Sb/TM3Ser individuals and transgenic F1 flies were identified by appearance of red eye color.

Immunostaining

488 5-10 pairs of ovaries were dissected in PBS and immediately fixed in 2\% PFA in PBSTX(0.1\%) (PBS

$489+0.1 \%$ Triton-X100) on a Nutator for $20 \mathrm{~min}$ at RT, followed by two washes of 15 min each with 490 PBSTX(0.1\%) shaking at RT. Ovaries were then blocked in 1X casein/PBSTX(0.1\%) (stock: 10X 491 casein blocking buffer, Sigma) for $30 \mathrm{~min}$ and incubated with rabbit anti-Egl primary antibody (kind gift 492 from R. Lehmann, Mach \& Lehmann, 1997) diluted in blocking buffer o/n at $4^{\circ} \mathrm{C}$. Alexa fluor 647 goat 493 anti Rabbit (Jackson Immuno Research) secondary antibody was added in blocking buffer for $2 \mathrm{~h}$ at 494 RT. Samples were washed 3x 10 min with 1X casein/PBSTX(0.1\%), 1x 10 min with PBSTX(0.1\%) + $4951: 15,000$ DAPI and kept o/n in $100 \mu \mathrm{l}$ of $80 \%$ TDE/PBS before mounting on microscope slides.

497 Single molecule in situ Fluorescence Hybridization (smFISH)

498 smFISH antisense oligonucleotides (listed in Table S2) were designed and labelled with dye499 conjugated ddUTPs according to the protocol described by Gáspár et al. (2017) to generate 500 oligonucleotides labelled at their 3' and with ATTO-633-NHS ester (ATTO-TEC). When dual-color 501 smFISH experiments were performed, each probe set was labelled with either ATTO-633 or ATTO565. The degree of labelling (DOL, \% of labelled oligos) and concentration of the labelled probe sets

503 was measured according to the published algorithm.

504 Dissected ovaries were immediately fixed in $2 \%$ PFA/PBSTX $(0.1 \%)$ gently shaking for 20 min at RT.

505 In case of ex vivo ovary incubation, dissected ovaries were incubated in Schneider's medium

506 supplemented with the respective pharmacological treatment before proceeding with fixation, as

507 described above. Fixed ovaries were rinsed and washed twice with PBSTX(0.1\%) for 10 min before 508 dehydrating them by replacing PBSTX(0.1\%) with increasing concentrations of ethanol/PBSTX( $0.1 \%)$.

509 Fixed and dehydrated ovaries were kept in $100 \%$ ethanol at $-20^{\circ} \mathrm{C}$ for up to 10 days until the day of 510 the experiment.

511 An optimized version of the smFISH protocol described in Hampoelz et al. (2019) was followed with 512 minor modifications. All steps were performed at RT unless specified otherwise. Dehydrated ovaries 
513 were first rinsed with PBSTX(0.1\%), followed by $2 \times 15$ min washes with PBSTX( $0.1 \%)$, and incubated

514 in Pre-hybridization Buffer (2x SSC, 10\% deionized formamide, 0.1\% Tween-20) gently shaking for 30

515 min. The Pre-hybridization Buffer was replaced with $250 \mu$ of Hybridization Buffer (2x SSC, 10\%

516 deionized formamide, 0.1\% Tween-20, 2 mM vanadyl ribonucleoside complex (New England Biolabs),

$517100 \mu \mathrm{g} / \mathrm{mL}$ salmon sperm DNA (Invitrogen), $10 \%$ dextran sulfate, $20 \mu \mathrm{g} / \mathrm{mL} \mathrm{BSA}$ ) pre-warmed at $37^{\circ} \mathrm{C}$

518 in which smFISH probes were added to a final concentration of $1 \mathrm{nM} / \mathrm{probe}$. Ovaries were kept

519 hybridizing in the dark for $16-17 \mathrm{~h}$ on a heat block set at $37^{\circ} \mathrm{C}$ shaking at $1000 \mathrm{rpm}$. To remove the

520 excess probes, ovaries where washed $3 \times 10 \mathrm{~min}$ at $37^{\circ} \mathrm{C}$ with Washing Buffer $(2 \times \mathrm{SSC}, 10 \%$

521 deionized formamide, 0.1\% Tween-20). 1:15,000 DAPI was added to the second wash. Finally,

522 samples were rinsed $4 x$ in PBST(0.1\%) (PBS $+0.1 \%$ Tween20) and kept in in $100 \mu$ l of $80 \%$

523 TDE/PBS for at least $1 \mathrm{~h}$ before mounting on microscope slides.

524 Z-stacks of images were acquired on a Leica TCS SP8 confocal microscope with 405nm, $488 \mathrm{~nm}, 552$

$525 \mathrm{~nm}$ and $640 \mathrm{~nm}$ fixed excitation laser lines using a 63X 1.3 NA glycerol immersion objective. A suitable

526 range for spectral detection was carefully chosen for each channel to avoid cross-talk of fluorescence

527 emission. Images were automatically restored by deconvolution with the Lightning module.

529 Image analysis and statistical testing

530 To quantify smFISH fluorescence of localizing RNAs, average Z-projections of deconvolved confocal

531 image stacks were analyzed with Fiji (Schindelin et al., 2012). In mosaic FE, for each wild-type (wt,

532 unmarked) and mutant (mCherry-marked) group of cells within the same Z-stack, a region of interest

533 (ROI) was drawn encompassing the apical and the basal cytoplasm of 5-10 adjacent follicle cells (with

534 the exclusion of nuclei); in addition, a ROI was drawn in an area of the image were no signal was

535 present (background, bg). The mean fluorescence intensity (m.f.i.) was measured for each ROI.

536 The degree of apicality (DoA) of a given RNA in each cell type (t) (wild-type or mutant) and each

537 experimental condition $c$, was measured as follows:

$$
D o A_{t, c}=\left(\frac{\text { Apical m. } f \cdot i_{t}-b g m \cdot f \cdot i}{\text { Basalm.f.it }{ }_{t}-b g m \cdot f \cdot i}\right)_{c}
$$

539 To quantitatively analyze changes in RNA localization in each experimental condition $c$, the DoA

540 measured in mutant (KD) cells was divided by the DoA measured in neighboring wild-type (wt) cells

541 within the same Z-stack: 


$$
K D / w t D o A_{c}=\left(\frac{D o A_{K D}}{D o A_{w t}}\right)_{c}
$$

543 Only in $T m 1^{\text {NULL }}$ condition, due to the impossibility to obtain a mosaic tissue, the DoA of a given RNA

544 in each cell type $(t)$ (wild-type or Tm1 $1^{\text {NULL }}$ ), was measured as follows:

$$
D o A_{t}=\left(\frac{\text { Apicalm.f.i }- \text { bgm.f.i }}{\text { Basalm.f.i }- \text { bgm.f.i }}\right)_{t}
$$

546 To calculate the change in DoA, the DoA measured in single $T m 1^{\text {NULL }}$ egg chambers was divided by

547 the average DoA measured in $n$ wild-type egg chambers (wt):

$$
T m 1 N U L L / w t D o A=\frac{D o A_{T m 1 N U L L}}{\frac{1}{n} \sum D o A_{w t}}
$$

In Figure 2D, Figure 3C, and Figure 5D, KD/wt DoA values of each RNA and experimental condition means to a reference value of $\mathrm{mu}=1$ in each experimental condition.

554 In Figure S3B, independent Student's $t$-test was used to compare mean DoA(wt) and DoA(RNAi)

555 values in each condition. In Figure S3C, mean KD/wt DoA values across conditions were compared by one-way ANOVA followed by Tukey's post-hoc tests.

\section{Other image analysis and statistical procedures}

559 Fluorescence intensity along lines were measured with Fiji on average Z-projections of confocal

560 images and plotted with R Studio. Intensity values from each channel were normalized to 0-1 range.

561 BicD, GFP, Bsg25D or hook mean fluorescence intensity along the A-B axis of the epithelium was

562 measured in groups of 5-10 adjacent follicle cells as line plots. At least 3 line plots were generated for

563 each RNA measured in each condition. The value corresponding to $50 \%$ of the cumulative area under

564 the curve (a.u.c.) of each plot was considered as the variation of the respective RNA localization along

565 the A-B axis of the epithelium. Welch two sample t-test was used to compare mean values of the $50 \%$

566 of the a.u.c with respect to untreated controls (pharmacological experiments) or in-frame BicD-GFP

567 (Frameshift vs. In-frame variation). 


\section{DATA AVAILABILITY}

570 The authors declare that all data supporting the findings of this study are available within the article

571 and its supplementary information files or from the corresponding author upon reasonable request.

572 RNA-seq data have been deposited in the ArrayExpress database at EMBL-EBI

573 (www.ebi.ac.uk/arrayexpress) under accession number E-MTAB-9127.

574

AUTHOR CONTRIBUTIONS

576 Conceptualization, L.C. and A.E.; Investigation, L.C.; Data Analysis, L.C; Writing - Original Draft, L.C.;

577 Writing - Review \& Editing, L.C. and A.E; Supervision, A.E.; Funding Acquisition, A.E.

\section{ACKNOWLEDGEMENTS}

580 We thank the Bloomington Drosophila Stock Center (BDSC), J. M. Gomez Elliff, A. Debec, I. Gaspar,

581 S. Bullock, J. R. Huynh and R. Lehmann for providing fly lines and reagents. We are grateful to I.

582 Gaspar for helpful discussions and K. Zarnack for training and advice in bioinfomatic analysis. We

583 thank the EMBL GeneCore Facility (D. Pavlinic, V. Benes), Advanced Light Microscopy Facility (S.

584 Terjung), Drosophila Injection Service (A. Reversi), Centre for Bioimage Analysis (C. Tischer), W.

585 Huber and the Centre for Statistical Data Analysis (B. Klaus) and Genome Biology Computational

586 Support (C. Girardot) for their support. We are grateful to Kathi Zarnack, Paolo Ronchi, Luigi Russo,

587 Alessandra Reversi and members of the Ephrussi lab for critically reading the manuscript. This work

588 was supported by EMBL. L.C. was supported by DFG-FOR 2333 grants EP 37/2-1 and EP 37/4-1

589 from the Deutsche Forschungsgemeinschaft (Germany) to A.E.

\section{DECLARATION OF INTERESTS}

592 The authors declare no competing financial interests.

\section{REFERENCES} online at: http://www.bioinformatics.babraham.ac.uk/projects/fastqcl protein indicates local translation on endosomes and is required for correct septin filamentation. 
bioRxiv preprint doi: https://doi.org/10.1101/2021.12.05.471303; this version posted December 7,2021 . The copyright holder for this preprint (which was not certified by peer review) is the author/funder, who has granted bioRxiv a license to display the preprint in perpetuity. It is made available under aCC-BY-NC-ND 4.0 International license.

Bhagavatula S, Knust E (2021) A putative stem-loop structure in Drosophila crumbs is required for mRNA localisation in epithelia and germline cells. J Cell Sci 134

Blower MD, Feric E, Weis K, Heald R (2007) Genome-wide analysis demonstrates conserved localization of messenger RNAs to mitotic microtubules. J Cell Biol 179: 1365-1373

Bolger AM, Lohse M, Usadel B (2014) Trimmomatic: A flexible trimmer for Illumina sequence data. Bioinformatics 30: 2114-2120

Brendza RP, Serbus LR, Duffy JB, Saxton WM, Brendza RP, Serbus LR, Duffy JB, Saxton WM (2000) A Function for Kinesin I in the Posterior Transport of oskar mRNA and Staufen Protein. Science (80- ) 289: 2120-2122

Bullock SL, Nicol A, Gross SP, Zicha D (2006) Guidance of Bidirectional Motor Complexes by mRNA Cargoes through Control of Dynein Number and Activity. Curr Biol 16: 1447-1452

Bullock SL, Ish-Horowicz D (2001) Conserved signals and machinery for RNA transport in Drosophila oogenesis and embryogenesis. Nature 414: 611-616

Cavener DR (1987) Comparison of the consensus sequence flanking translational start sites in Drosophila and vertebrates. Nucleic Acids Res 15: 1353-1361

Cha B-J, Serbus LR, Koppetsch BS, Theurkauf WE (2002) Kinesin I-dependent cortical exclusion restricts pole plasm to the oocyte posterior. Nat Cell Biol 4: 592-598

Chen J, Suo S, Tam PP, Han JDJ, Peng G, Jing N (2017) Spatial transcriptomic analysis of cryosectioned tissue samples with Geo-seq. Nat Protoc 12: 566-580

Chowdhury S, Ketcham SA, Schroer TA, Lander GC (2015) Structural organization of the dyneindynactin complex bound to microtubules. Nat Struct Mol Biol 22: 345-347

Cioni JM, Lin JQ, Holtermann A V., Koppers M, Jakobs MAH, Azizi A, Turner-Bridger B, Shigeoka T, Franze K, Harris WA, et al (2019) Late Endosomes Act as mRNA Translation Platforms and Sustain Mitochondria in Axons. Cell 176: $56-72$

Clark A, Meignin C, Davis I (2007) A Dynein-dependent shortcut rapidly delivers axis determination transcripts into the Drosophila oocyte. Development 134: 1955-1965

Clark IE, Jan LY, Jan YN (1997) Reciprocal localization of nod and kinesin fusion proteins indicates microtubule polarity in the Drosophila oocyte, epithelium, neuron and muscle. Development 124: $461-470$

Cohen B, Golani-Armon A, Altman T, Savulescu AF, Mhlanga MM, Perlson E, Arava YS (2021) Mitochondria serve as axonal shuttle for Cox7c mRNA through mechanism that involves its mitochondrial targeting signal. bioRxiv: 2021.05.19.444640

Corradi E, Dalla Costa I, Gavoci A, Iyer A, Roccuzzo M, Otto TA, Oliani E, Bridi S, Strohbuecker S, Santos-Rodriguez G, et al (2020) Axonal precursor miRNAs hitchhike on endosomes and locally regulate the development of neural circuits. EMBO J 39: 1-24

Coutelis JB, Ephrussi A (2007) Rab6 mediates membrane organization and determinant localization during Drosophila oogenesis. Development 134: 1419-1430

Delanoue R, Davis I (2005) Dynein anchors its mRNA cargo after apical transport in the Drosophila blastoderm embryo. Cell 122: 97-106 
bioRxiv preprint doi: https://doi.org/10.1101/2021.12.05.471303; this version posted December 7,2021 . The copyright holder for this preprint (which was not certified by peer review) is the author/funder, who has granted bioRxiv a license to display the preprint in perpetuity. It is made available under aCC-BY-NC-ND 4.0 International license.

Delanoue R, Herpers B, Soetaert J, Davis I, Rabouille C (2007) Drosophila Squid/hnRNP Helps Dynein Switch from a gurken mRNA Transport Motor to an Ultrastructural Static Anchor in Sponge Bodies. Dev Cell 13: 523-538

Dienstbier M, Boehl F, Li X, Bullock SL (2009) Egalitarian is a selective RNA-binding protein linking mRNA localization signals to the dynein motor. Genes Dev 23: 1546-1558

Dimitrova-Paternoga L, Jagtap PKA, Cyrklaff A, Vaishali, Lapouge K, Sehr P, Perez K, Heber S, Löw C, Hennig J, et al (2021) Molecular basis of mRNA transport by a kinesin-1-atypical tropomyosin complex. Genes Dev 35: 1-16

Dobin A, Davis CA, Schlesinger F, Drenkow J, Zaleski C, Jha S, Batut P, Chaisson M, Gingeras TR (2013) STAR: Ultrafast universal RNA-seq aligner. Bioinformatics 29: 15-21

Erdélyi M, Michon AM, Guichet A, Glotzer JB, Ephrussi A (1995) Requirement for Drosophila cytoplasmic tropomyosin in oskar mRNA localization. Nature 377: 524-527

Gardiol A, St Johnston D (2014) Staufen targets coracle mRNA to Drosophila neuromuscular junctions and regulates GluRIIA synaptic accumulation and bouton number. Dev Biol 392: 153-167

Gáspár I, Phea LJ, Ephrussi A (2021) Egalitarian feeds forward to Staufen to inhibit Dynein during mRNP transport. bioRxiv: 2021.04.24.441269

Gáspár I, Sysoev V, Komissarov A, Ephrussi A (2016) An RNA-binding atypical tropomyosin recruits kinesin-1 dynamically to oskar mRNPs. EMBO J 36: 319-333

Gáspár I, Wippich F, Ephrussi A (2017) Enzymatic production of single-molecule FISH and RNA capture probes. Rna 23: 1582-1591

Ghosh S, Obrdlik A, Marchand V, Ephrussi A (2014) The EJC Binding and Dissociating Activity of PYM Is Regulated in Drosophila. PLoS Genet 10: e1004455

Goldspink DA, Rookyard C, Tyrrell BJ, Gadsby J, Perkins J, Lund EK, Galjart N, Thomas P, Wileman T, Mogensen MM (2017) Ninein is essential for apico-basal microtubule formation and CLIP-170 facilitates its redeployment to non-centrosomal microtubule organizing centres. Open Biol 7

González-Reyes A, St Johnston D (1998) Patterning and morphogenesis of the follicle cell epithelium during Drosophila oogenesis. Development 125: 2837-2846

Gu Z, Eils R \& Schlesner M (2016) Complex heatmaps reveal patterns and correlations in multidimensional genomic data. Bioinformatics 32: 2847-2849

Hachet O, Ephrussi A (2001) Drosophila Y14 shuttles to the posterior of the oocyte and is required for oskar mRNA transport. Curr Biol 11: 1666-1674

Hampoelz B, Schwarz A, Ronchi P, Bragulat-Teixidor H, Tischer C, Gaspar I, Ephrussi A, Schwab Y, Beck M (2019) Nuclear Pores Assemble from Nucleoporin Condensates During Oogenesis. Cell 179: $671-686 . e 17$

Hancock WO (2014) Bidirectional cargo transport: Moving beyond tug of war. Nat Rev Mol Cell Biol 15: $615-628$

Harbauer AB, Wanderoy S, Hees JT, Gibbs W, Ordonez M, Cai Z, Cartoni R, Ashrafi G, Wang C, He $Z$, et al (2021) Neuronal mitochondria transport Pink1 mRNA via Synaptojanin 2 to support local mitophagy. bioRxiv: 2021.05.19.444778 
bioRxiv preprint doi: https://doi.org/10.1101/2021.12.05.471303; this version posted December 7, 2021. The copyright holder for this preprint (which was not certified by peer review) is the author/funder, who has granted bioRxiv a license to display the preprint in perpetuity. It is made available under aCC-BY-NC-ND 4.0 International license.

Hoogenraad CC, Akhmanova A, Howell SA, Dortland BR, De Zeeuw Cl, Willemsen R, Visser P, Grosveld F, Galjart N (2001) Mammalian golgi-associated Bicaudal-D2 functions in the dyneindynactin pathway by interacting with these complexes. EMBO J 20: 4041-4054

Hoogenraad CC, Wulf P, Schiefermeier N, Stepanova T, Galjart N, Small JV, Grosveld F, De Zeeuw $\mathrm{Cl}$, Akhmanova A (2003) Bicaudal D induces selective dynein-mediated microtubule minus enddirected transport. EMBO J 22: 6004-6015

Horne-Badovinac S, Bilder D (2008) Dynein regulates epithelial polarity and the apical localization of stardust A mRNA. PLoS Genet 4: 0040-0051

Hughes JR, Bullock SL, Ish-Horowicz D (2004) inscuteable mRNA Localization Is Dynein-Dependent and Regulates Apicobasal Polarity and Spindle Length in Drosophila Neuroblasts. Curr Biol 14: 1950-1956

Jambor H, Mueller S, Bullock SL, Ephrussi A (2014) A stem-loop structure directs oskar mRNA to microtubule minus ends. Rna 20: 429-439

Jambor H, Surendranath V, Kalinka AT, Mejstrik P, Saalfeld S, Tomancak P (2015) Systematic imaging reveals features and changing localization of mRNAs in Drosophila development. Elife 4: 1-22

Januschke J, Nicolas E, Compagnon J, Formstecher E, Goud B, Guichet A (2007) Rab6 and the secretory pathway affect oocyte polarity in Drosophila. Development 134: 3419-3425

Karlin-McGinness M, Serano TL, Cohen RS (1996) Comparative Analysis of the Kinetics and Dynamics of K10, bicoid, and oskar mRNA Localization in the Drosophila Oocyte. Dev Genet 19: 238-248

Khanal I, Elbediwy A, de la Loza M del CD, Fletcher GC, Thompson BJ (2016) Shot and Patronin polarise microtubules to direct membrane traffic and biogenesis of microvilli in epithelia. $J$ Cell Sci 129: 2651-2659

Kopylova E, Noé L, Touzet H (2012) SortMeRNA: Fast and accurate filtering of ribosomal RNAs in metatranscriptomic data. Bioinformatics 28: 3211-3217

Kwon OS, Mishra R, Safieddine A, Coleno E, Alasseur Q, Faucourt M, Barbosa I, Bertrand E, Spassky $\mathrm{N}$, Le Hir H (2021) Exon junction complex dependent mRNA localization is linked to centrosome organization during ciliogenesis. Nat Commun 12: 1-16

Larkin A, Marygold SJ, Antonazzo G, Attrill H, dos Santos G, Garapati P V, Goodman JL, Gramates LS, Millburn G, Strelets VB, et al (2021) FlyBase: updates to the Drosophila melanogaster knowledge base. Nucleic Acids Res 49: D899-D907

Lécuyer E, Yoshida H, Parthasarathy N, Alm C, Babak T, Cerovina T, Hughes TR, Tomancak P, Krause HM (2007) Global Analysis of mRNA Localization Reveals a Prominent Role in Organizing Cellular Architecture and Function. Cell 131: 174-187

Lee I-G, Cason SE, Alqassim SS, Holzbaur ELF, Dominguez R (2020) A tunable LIC1-adaptor interaction modulates dynein activity in a cargo-specific manner. Nat Commun 11: 5695

Li Z, Wang L, Hays TS, Cai Y (2008) Dynein-mediated apical localization of crumbs transcripts is required for Crumbs activity in epithelial polarity. J Cell Biol 180: 31-38

Liao YC, Fernandopulle MS, Wang G, Choi H, Hao L, Drerup CM, Patel R, Qamar S, Nixon-Abell J, Shen Y, et al (2019) RNA Granules Hitchhike on Lysosomes for Long-Distance Transport, Using Annexin A11 as a Molecular Tether. Cell 179: 147-164 
bioRxiv preprint doi: https://doi.org/10.1101/2021.12.05.471303; this version posted December 7,2021 . The copyright holder for this preprint (which was not certified by peer review) is the author/funder, who has granted bioRxiv a license to display the preprint in perpetuity. It is made available under aCC-BY-NC-ND 4.0 International license.

Liao Y, Smyth GK, Shi W (2014) FeatureCounts: An efficient general purpose program for assigning sequence reads to genomic features. Bioinformatics 30: 923-930

Love MI, Huber W, Anders S (2014) Moderated estimation of fold change and dispersion for RNA-seq data with DESeq2. Genome Biol 15: 1-21

Mach JM, Lehmann R (1997) An Egalitarian-BicaudalD Complex Is Essential for Oocyte Specification and Axis Determination in Drosophila. Genes Dev 11: 423-435

Matanis T, Akhmanova A, Wulf P, Del Nery E, Weide T, Stepanova T, Galjart N, Grosveld F, Goud B, De Zeeuw Cl, et al (2002) Bicaudal-D regulates COPI-independent Golgi-ER transport by recruiting the dynein-dynactin motor complex. Nat Cell Biol 4: 986-992

McKenney RJ, Huynh W, Tanenbaum ME, Bhabha G, Vale RD (2014) Activation of cytoplasmic dynein motility by dynactin-cargo adapter complexes. Science (80- ) 345: 337-341

Medioni C, Mowry K, Besse F (2012) Principles and roles of mRNA localization in animal development. Development 139: 3263-3276

Mili S, Moissoglu K, Macara IG (2008) Genome-wide screen reveals APC-associated RNAs enriched in cell protrusions. Nature 453: 115-119

Mohr SE, Dillon ST, Boswell RE (2001) The RNA-binding protein Tsunagi interacts with Mago Nashi to establish polarity and localize oskar mRNA during Drosophila oogenesis. Genes Dev 15: 28862899

Moor AE, Golan M, Massasa EE, Lemze D, Weizman T, Shenhav R, Baydatch S, Mizrahi O, Winkler $\mathrm{R}$, Golani O, et al (2017) Global mRNA polarization regulates translation efficiency in the intestinal epithelium. Science (80- ) 357: 1299-1303

Nakamura A, Amikura R, Hanyu K, Kobayashi S (2001) Me31B silences translation of oocytelocalizing RNAs through the formation of cytoplasmic RNP complex during Drosophila oogenesis. Development 128: 3233-3242

Navarro C, Puthalakath H, Adams JM, Strasser A, Lehmann R (2004) Egalitarian binds dynein light chain to establish oocyte polarity and maintain oocyte fate. Nat Cell Biol 6: 427-435

Newmark PA, Boswell RE (1994) The mago nashi locus encodes an essential product required for germ plasm assembly in Drosophila. Development 120: 1303-1313

Olenick MA, Holzbaur ELF (2019) Dynein activators and adaptors at a glance. J Cell Sci 132

Palacios IM, Gatfield D, St. Johnston D, Izaurralde E (2004) An elF4AIIl-containing complex required for mRNA localization and nonsense-mediated mRNA decay. Nature 427: 753-757

Pignoni F, Zipursky SL (1997) Induction of Drosophila eye development by decapentaplegic. Development 124: 271-278

Redwine WB, DeSantis ME, Hollyer I, Htet ZM, Tran PT, Swanson SK, Florens L, Washburn MP, Reck-Peterson SL (2017) The human cytoplasmic dynein interactome reveals novel activators of motility. Elife 6: 1-27

Robinson J, Thorvaldsdóttir H, Winckler W, Guttman M, Lander ES, Getz G, Mesirov JP (2011) Integrative genomics viewer. Nat Biotechnol 29: 24-26 doi:10.1038/nbt.1754 
bioRxiv preprint doi: https://doi.org/10.1101/2021.12.05.471303; this version posted December 7, 2021. The copyright holder for this preprint (which was not certified by peer review) is the author/funder, who has granted bioRxiv a license to display the preprint in perpetuity. It is made available under aCC-BY-NC-ND 4.0 International license.

Ronchi P, Mizzon G, Machado P, D'Imprima E, Best BT, Cassella L, Schnorrenberg S, Montero MG, Jechlinger M, Ephrussi A, et al (2021) High-precision targeting workflow for volume electron microscopy. J Cell Biol 220

Safieddine A, Coleno E, Salloum S, Imbert A, Traboulsi AM, Kwon OS, Lionneton F, Georget V, Robert MC, Gostan T, et al (2021) A choreography of centrosomal mRNAs reveals a conserved localization mechanism involving active polysome transport. Nat Commun 12: 1-21

Schindelin J, Arganda-Carreras I, Frise E, Kaynig V, Longair M, Pietzsch T, Preibisch S, Rueden C, Saalfeld S, Schmid B, et al (2012) Fiji: An open-source platform for biological-image analysis. Nat Methods 9: 676-682

Schlager MA, Serra-Marques A, Grigoriev I, Gumy LF, da Silva ME, Wulf PS, Akhmanova A, Hoogenraad CC (2014) Bicaudal D Family Adaptor Proteins Control the Velocity of DyneinBased Movements. Cell Rep 8: 1248-1256

Schotman H, Karhinen L, Rabouille C (2008) dGRASP-Mediated Noncanonical Integrin Secretion Is Required for Drosophila Epithelial Remodeling. Dev Cell 14: 171-182

Schroeder CM, Vale RD (2016) Assembly and activation of dynein-dynactin by the cargo adaptor protein Hook3. J Cell Biol 214: 309-318

Sepulveda G, Antkowiak M, Brust-Mascher I, Mahe K, Ou T, Castro NM, Christensen LN, Cheung L, Jiang X, Yoon D, et al (2018) Co-translational protein targeting facilitates centrosomal recruitment of PCNT during centrosome maturation in vertebrates. Elife 7: 1-28

Serano J, Rubin GM (2003) The Drosophila synaptotagmin-like protein bitesize is required for growth and has mRNA localization sequences within its open reading frame. Proc Natl Acad Sci U S A 100: $13368-13373$

Shepard KA, Gerber AP, Jambhekar A, Takizawa PA, Brown PO, Herschlag D, DeRisi JL, Vale RD (2003) Widespread cytoplasmic mRNA transport in yeast: Identification of 22 bud-localized transcripts using DNA microarray analysis. Proc Natl Acad Sci U S A 100: 11429-11434

Sladewski TE, Billington N, Ali MY, Bookwalter CS, Lu H, Krementsova EB, Schroer TA, Trybus KM (2018) Recruitment of two dyneins to an mRNA-dependent bicaudal D transport complex. Elife 7: e36306

Steinhauer J, Kalderon D (2006) Microtubule polarity and axis formation in the Drosophila oocyte. Dev Dyn an Off Publ Am Assoc Anat 235: 1455-1468

Struhl G, Basler K (1993) Organizing activity of wingless protein in Drosophila. Cell 72: 527-540

Stuurman N, Häner M, Sasse B, Hübner W, Suter B, Aebi U (1999) Interactions between coiled-coil proteins: Drosophila lamin Dm0 binds to the Bicaudal-D protein. Eur J Cell Biol 78: 278-287

Suter B, Steward R (1991) Requirement for phosphorylation and localization of the Bicaudal-D protein in Drosophila oocyte differentiation. Cell 67: 917-926

Tillery MML, Blake-Hedges C, Zheng Y, Buchwalter RA, Megraw TL (2018) Centrosomal and NonCentrosomal Microtubule-Organizing Centers (MTOCs) in Drosophila melanogaster. Cells 7: 121

Torisawa T, Ichikawa M, Furuta A, Saito K, Oiwa K, Kojima H, Toyoshima YY, Furuta K (2014) Autoinhibition and cooperative activation mechanisms of cytoplasmic dynein. Nat Cell Biol 16: 1118-1124 
bioRxiv preprint doi: https://doi org/10.1101/2021.12.05.471303; this version posted December 7,2021 . The copyright holder for this preprint (which was not certified by peer review) is the author/funder, who has granted bioRxiv a license to display the preprint in perpetuity. It is made available under aCC-BY-NC-ND 4.0 International license.

Trokter M, Mücke N, Surrey T (2012) Reconstitution of the human cytoplasmic dynein complex. Proc Natl Acad Sci 109: 20895 LP - 20900

Urnavicius L, Zhang K, Diamant AG, Motz C, Schlager MA, Yu M, Patel NA, Robinson C V, Carter AP (2015) The structure of the dynactin complex and its interaction with dynein. Science 347: 14411446

Van de Bor V, Zimniak G, Cérézo D, Schaub S, Noselli S (2011) Asymmetric localisation of cytokine mRNA is essential for JAK/STAT activation during cell invasiveness. Development 138: 13831393

Vazquez-Pianzola P, Schaller B, Colombo M, Beuchle D, Neuenschwander S, Marcil A, Bruggmann $\mathrm{R}$, Suter $\mathrm{B}$ (2017) The mRNA transportome of the BicD/Egl transport machinery. RNA Biol 14: 73-89

Wharton RP, Struhl G (1989) Structure of the Drosophila BicaudalD protein and its role in localizing the posterior determinant nanos. Cell 59: 881-892

Wilk R, Hu J, Blotsky D, Krause HM (2016) Diverse and pervasive subcellular distributions for both coding and long noncoding RNAs. Genes Dev 30: 594-609

Wilkie GS, Davis I (2001) Drosophila wingless and pair-rule transcripts localize apically by dyneinmediated transport of RNA particles. Cell 105: 209-219

Xing L, Bassell GJ (2013) MRNA localization: An orchestration of assembly, traffic and synthesis. Traffic 14: 2-14

Zhang K, Foster HE, Rondelet A, Lacey SE, Bahi-Buisson N, Bird AW, Carter AP (2017) Cryo-EM Reveals How Human Cytoplasmic Dynein Is Auto-inhibited and Activated. Cell 169: 13031314.e18

Zimyanin VL, Belaya K, Pecreaux J, Gilchrist MJ, Clark A, Davis I, St Johnston D (2008) In Vivo Imaging of oskar mRNA Transport Reveals the Mechanism of Posterior Localization. Cell 134: 843-853 
bioRxiv preprint doi: https://doi org/10.1101/2021.12 05.471303. this version posted December 7, 2021. The copyright holder for this

preprint (which was not certified by peer review) is the author/funder, who has granted bioRxiv a license to display the preprint in perpetuity. It is made available under aCC-BY-NC-ND 4.0 International license.

\section{MAIN FIGURES AND LEGENDS}

Figure 1

A
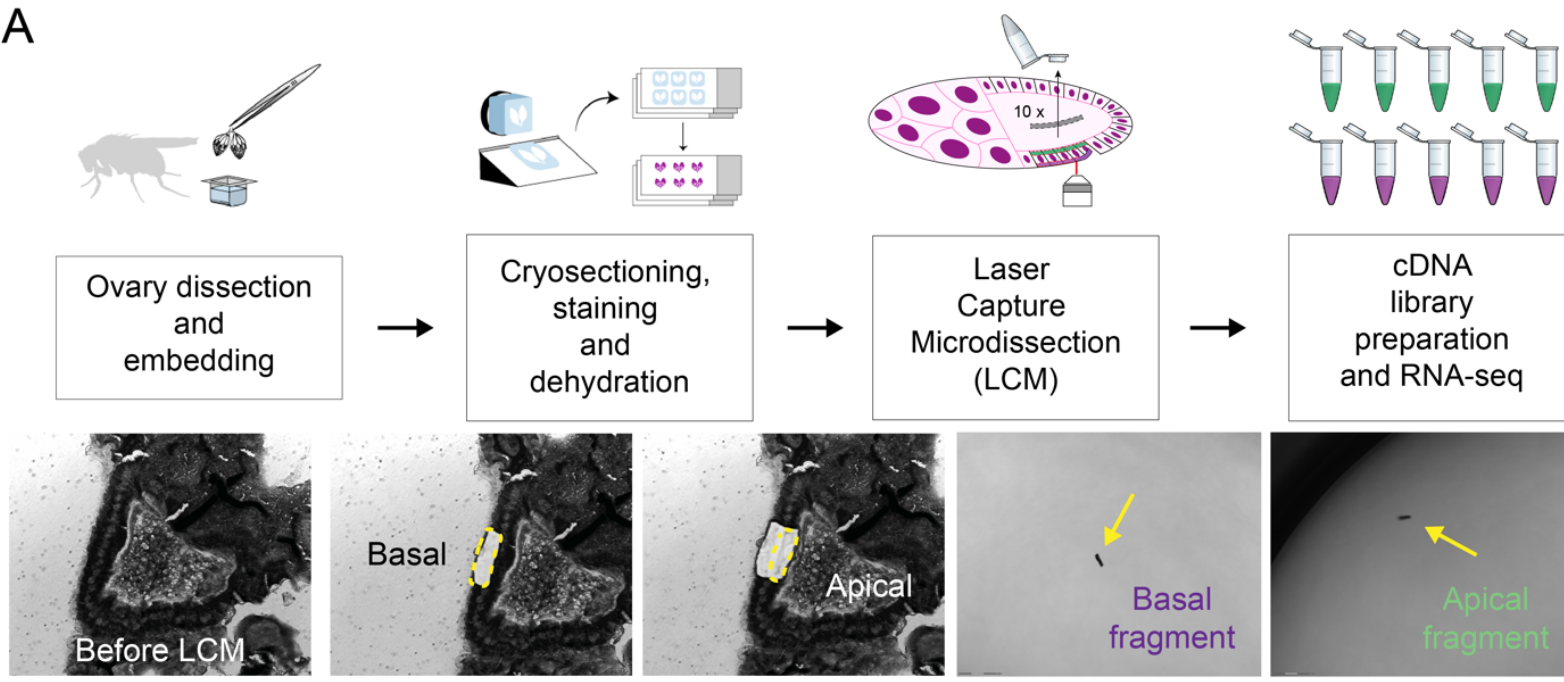

B

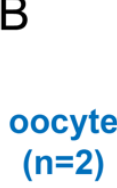

Apical mRNAs $(n=304)$

Basal mRNAs $(n=216)$

muscle $(n=33)$ row Z-score $420-2-4$
Basal fragments fragments

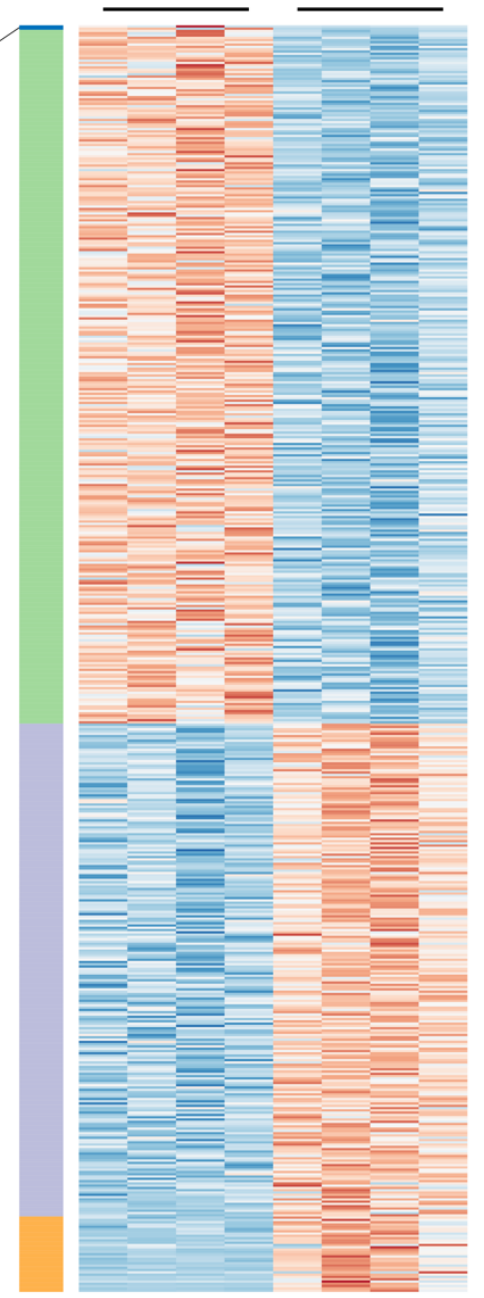

$4-2-2-4$

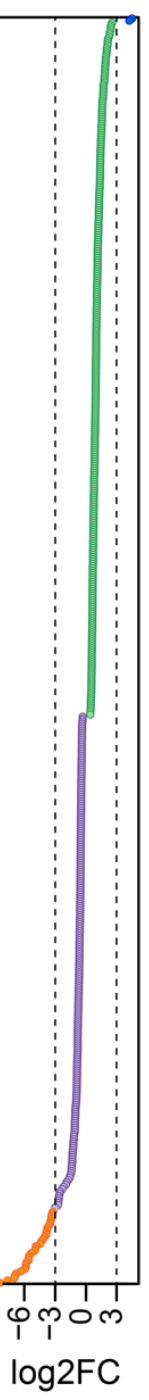

C

Apical RNAs

Basal RNAs
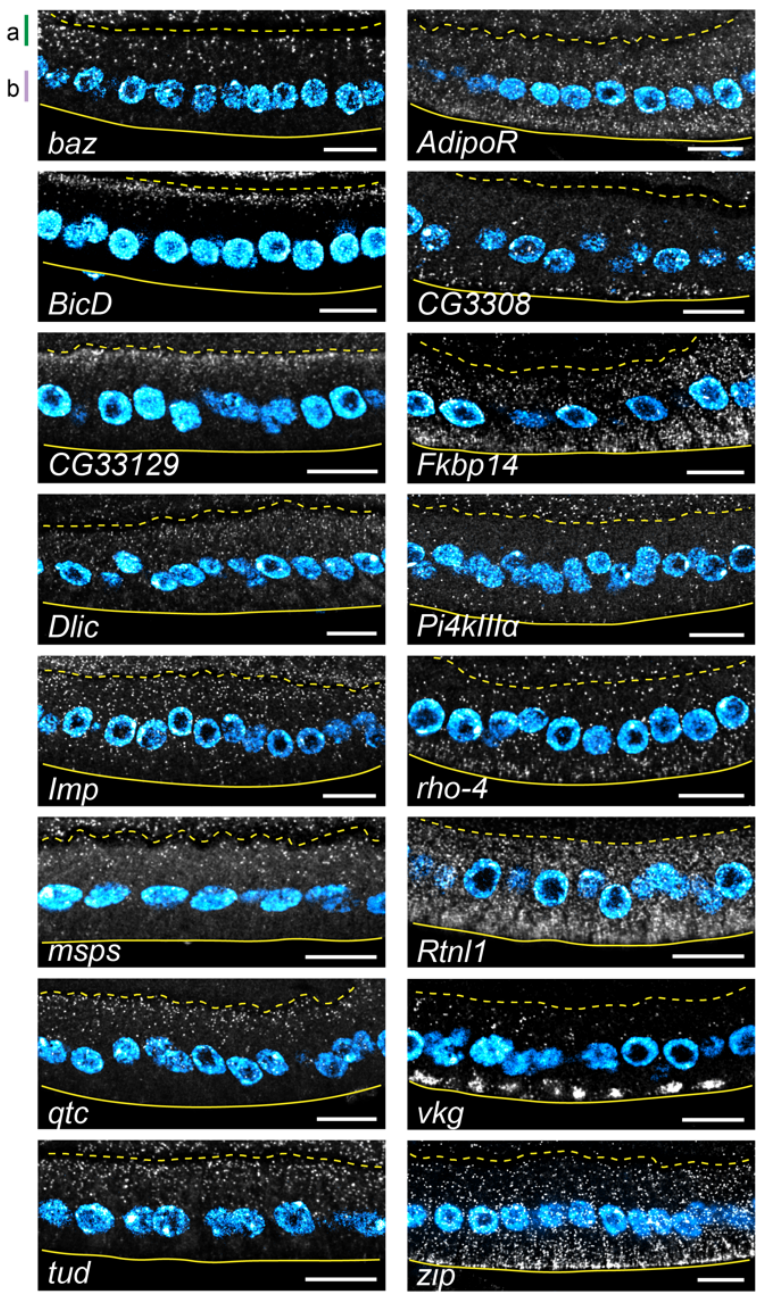

$\log 2 \mathrm{FC}$ 
827 Figure 1. Identification of apical and basal RNAs in Drosophila follicular epithelium by

828 subcellular spatial transcriptomics. A) Schematic representation of the sample preparation

829 procedure. Lower panels: representative images of an egg chamber before and after apical and basal

830 fragment microdissection, including visualization of microdissected fragments in the cap of collection

831 tubes. B) Heatmap representing RNA-seq signal (z-score of normalized read counts) for significantly

832 enriched RNAs in microdissected apical and basal fragments (FDR $<0.1)$. Each row represents a

833 significantly enriched RNA in either apical samples $(n=4)$ or basal samples $(n=4)$. The log2FC value of

834 each RNA showed in the heatmap is indicated in the graph on the right. Dashed lines indicate

835 threshold $\log 2 \mathrm{FC}$ values $(\log 2 \mathrm{FC}<-3$ and $\log 2 \mathrm{FC}>3)$ arbitrarily set to identify oocyte contaminants

836 ( $\log 2 \mathrm{FC}>3, \mathrm{n}=2$, blue), bona fide apical RNAs $(0<\log 2 \mathrm{FC} \leq 3, \mathrm{n}=304$, green), bona fide basal RNAs

$837(-3 \leq \log 2 \mathrm{FC}<0, n=216$, purple), and muscle contaminants (log2FC $\leq-3, n=33$, orange). $C) s m F I S H$

838 validation of 16 bona fide apical (left panels) and basal (right panels) RNAs. A dashed line and a

839 continuous line in each panel delimit the FC-oocyte and FC-basal lamina borders respectively. $a=$

840 apical domain; $b=$ basal domain. Nuclei (cyan) are stained with DAPI. Scale bars $10 \mu \mathrm{m}$. See also

841 Figure S1, Table S1 and Video S1.

842

843 
bioRxiv preprint doi: https://doi.org/10.1101/2021.12.05.471303; this version posted December 7, 2021. The copyright holder for this preprint (which was not certified by peer review) is the author/funder, who has granted bioRxiv a license to display the preprint in perpetuity. It is made available under aCC-BY-NC-ND 4.0 International license.

\section{A Khc RNAi mosaic tissue}

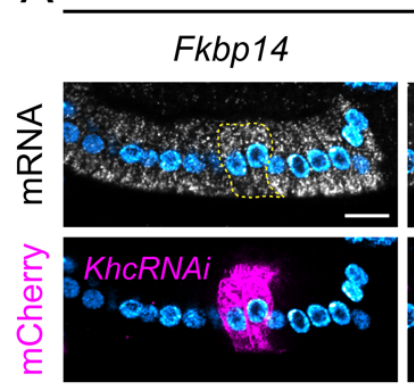

B $\quad F k b p 14$

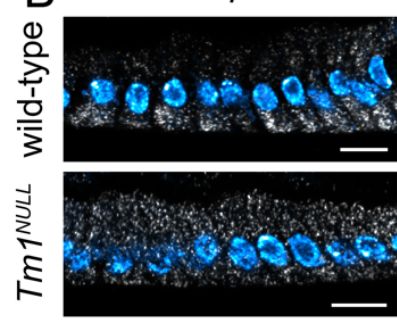

C

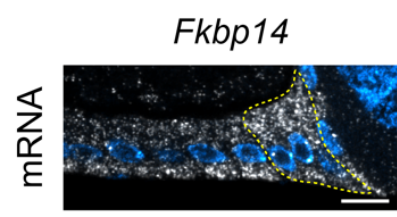

$\frac{\cap}{5}$
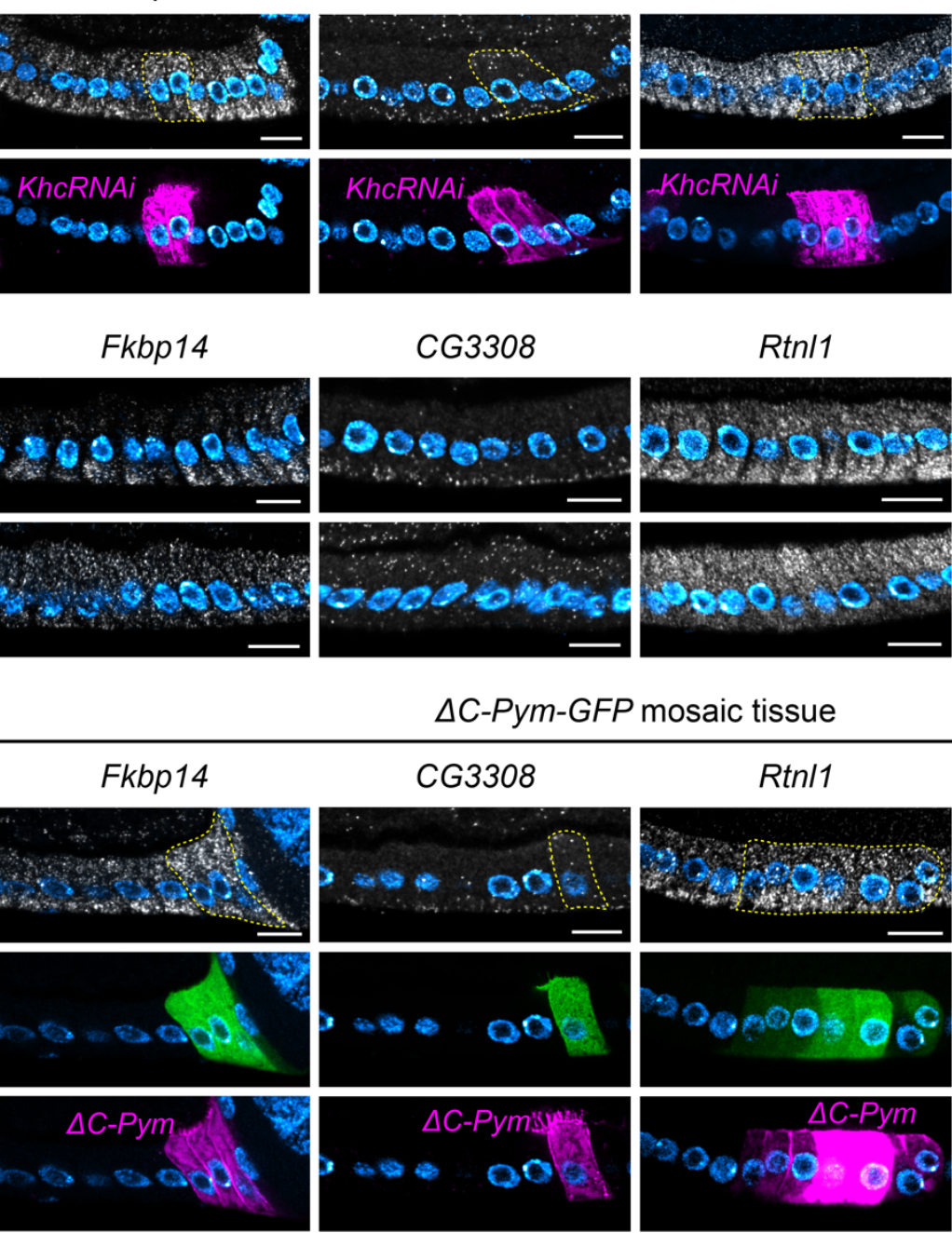

Rtnl1

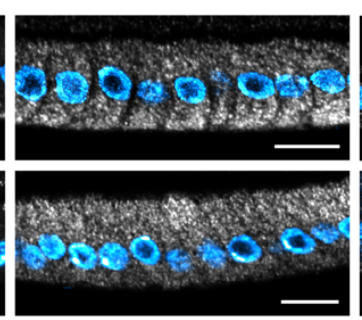

$\triangle C$-Pym-GFP mosaic tissue
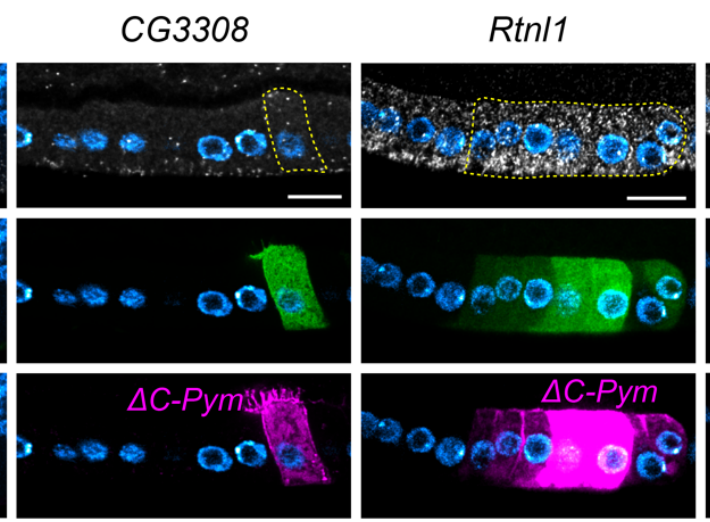

D

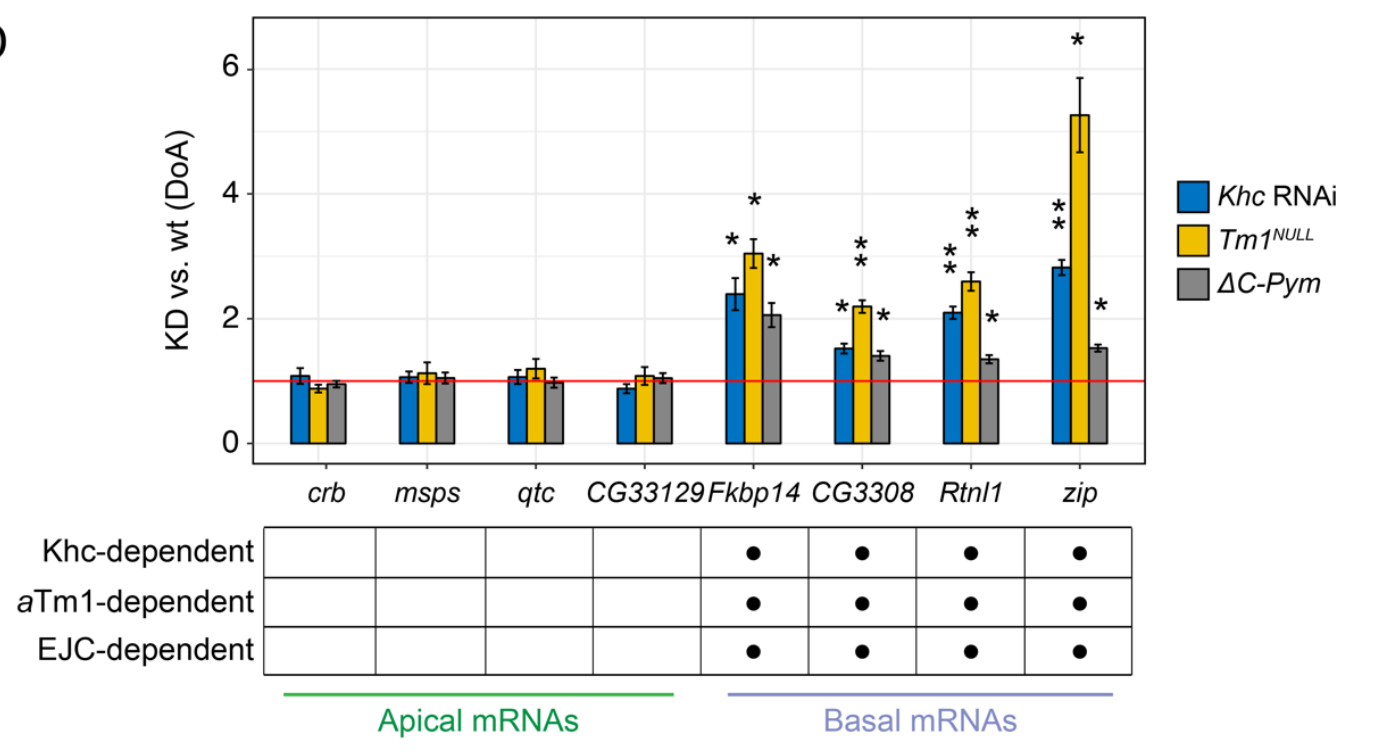




\section{Figure 2. Basal RNA localization depends on kinesin-1, aTm1, and the EJC.}

848 In A) and C), mutant cells (marked with CD8-mCherry, lower panels) were generated by the UAS/Gal4

849 FLP-out system by inducing Khc RNAi (A) or by expressing the EJC-disrupting protein $\triangle C$-Pym (C), to 850 disrupt each component without significantly affecting tissue architecture. Neighboring wild-type cells

851 are unmarked. A dashed line highlights mutant cells in smFISH images (upper panels). In B) the

852 expression of the $a T m 1$ isoform was specifically knocked down by generating $T m 1^{\text {eg9 }} / T m 1^{\text {eg } 1}$

853 (Tm1 $1^{\text {NULL }}$ ) egg chambers. A) Localization of basal RNAs by smFISH in Khc RNAi mosaic tissue. B)

854 Localization of basal RNAs by smFISH in wild-type and Tm $1^{\text {NULL }}$ egg chambers. C) Localization of

855 basal RNAs by smFISH in $\triangle C$-Pym-GFP mosaic tissue. D) Quantification of changes in the A-B

856 distribution of apical and basal RNAs in conditions of downregulated kinesin-1 transport. Analyzed

857 RNAs are indicated on the $x$-axis. The $y$-axis shows the average values ( \pm s.e.m) of the ratio between

858 the Degree of Apicality (DoA) measured in knock-down (KD) cells and the DoA measured in wild-type

859 (wt) cells for each RNA analyzed, in each of the three conditions. The mean KD/wt(DoA) value for

860 each RNA in each condition was tested against a null hypothesis $H_{0}$ of $K D / w t(D \circ A)=1$ (red horizontal

861 line), corresponding to no change between mutant and wild-type cells (one-sample t-test). Asterisks

862 indicate mean values that significantly differ from the reference value of $m u=1\left({ }^{*}=p<0.05 ;{ }^{* *}=p<0.01\right.$;

$\left.863^{* * *}=p<0.001\right)$. Nuclei (cyan) are stained with DAPI. Scale bars $10 \mu \mathrm{m}$. See also Figure S2 and Figure

864 S3.

865 
bioRxiv preprint doi: https://doi.org/10.1101/2021.12.05.471303; this version posted December 7 2021. The copyright holder for this preprint (which was not certified by peer review) is the author/funder, who has granted bioRxiv a license to display the preprint in perpetuity. It is made available under aCC-BY-NC-ND 4.0 International license.

\section{$866 \quad$ Figure 3}

867

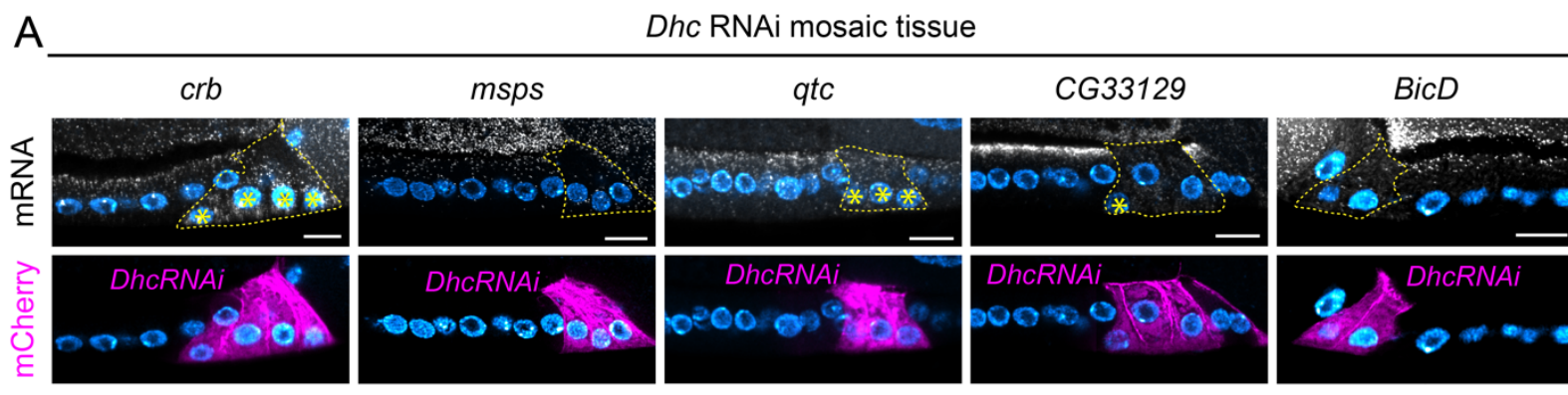

B

egl RNAi mosaic tissue
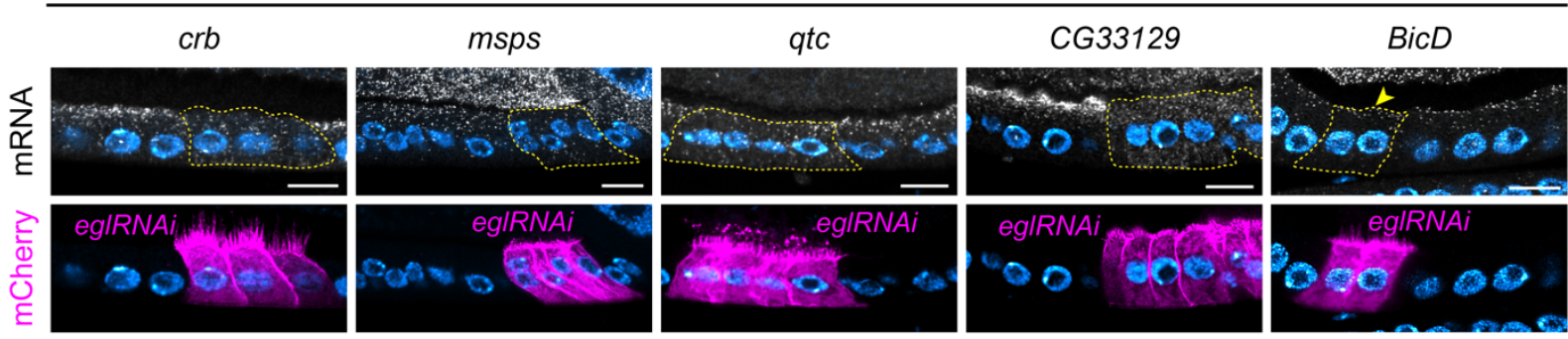

C

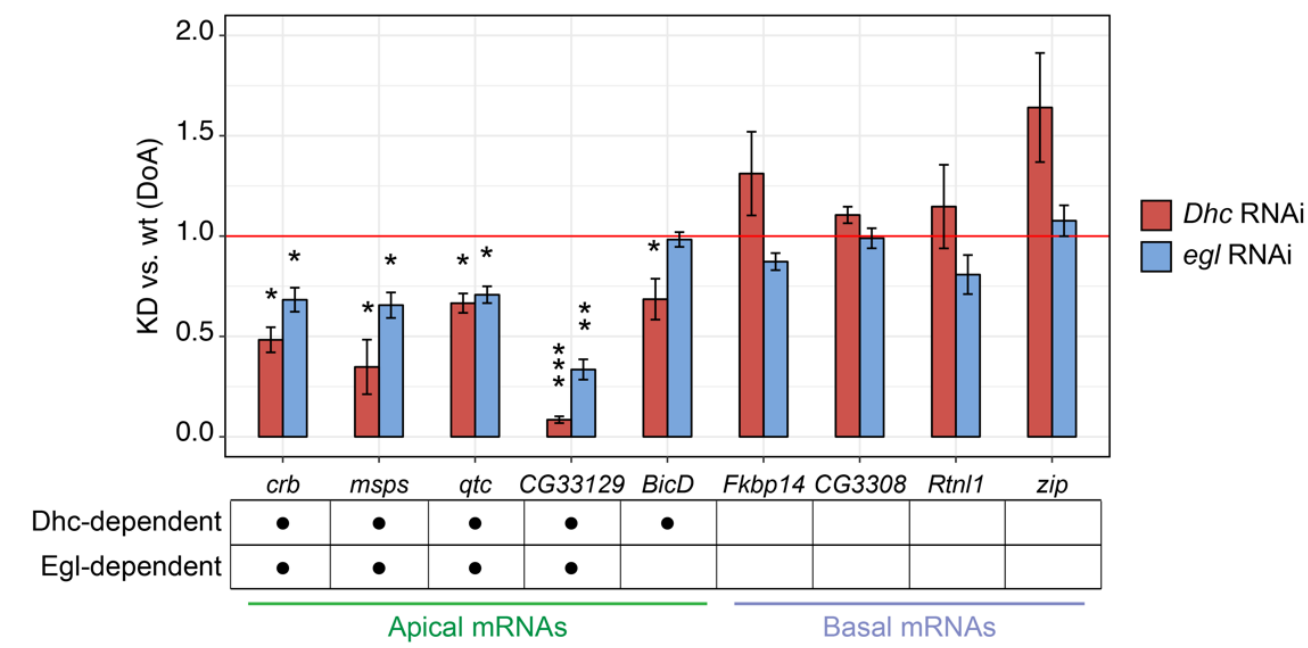


870 Figure 3. Two different dynein-dependent mechanisms control apical RNA localization.

871 A-B) Localization of apical RNAs by smFISH in Dhc RNAi (A) and egl RNAi mosaic tissue (B). Mutant

872 cells are marked by the expression of CD8-mCherry (lower panels) and highlighted with a dashed line

873 in smFISH images (upper panels). Neighboring wild-type cells are unmarked. Asterisks $\left(^{*}\right)$ indicate

874 basal mispositioning of nuclei due to Dhc RNAi, an indication of mild cell polarity defects. The

875 arrowhead in B) indicates the persistence of apical BicD RNA in eg/ RNAi cells. C) Quantification of

876 changes in the A-B distribution of apical and basal RNAs in conditions of downregulated

877 dynein/BicD/Egl transport (Dhc RNAi or egl RNAi). Analyzed RNAs are indicated on the x-axis. The y-

878 axis shows the average values ( \pm s.e.m) of the $\mathrm{KD} / \mathrm{wt}$ ratio (DoA) for each RNA analyzed, in each of

879 the two conditions. The mean KD/wt(DoA) value for each RNA in each condition was tested against a

880 value of $K D / w t(D \circ A)=1$ (red horizontal line), corresponding to no change between mutant and wild-

881 type cells (one-sample t-test). Asterisks indicate mean values that significantly differ from the

882 reference value of $m u=1\left({ }^{*}=p<0.05 ;{ }^{* *}=p<0.01 ;{ }^{* * *}=p<0.001\right)$. Nuclei (cyan) are stained with DAPI.

883 Scale bars $10 \mu \mathrm{m}$. See also Figure S4.

884 
bioRxiv preprint doi: https://doi org/10.1101/2021.12 05.471303. this version posted December 7, 2021. The copyright holder for this

preprint (which was not certified by peer review) is the author/funder, who has granted bioRxiv a license to display the preprint in perpetuity. It is made available under aCC-BY-NC-ND 4.0 International license.

886

A

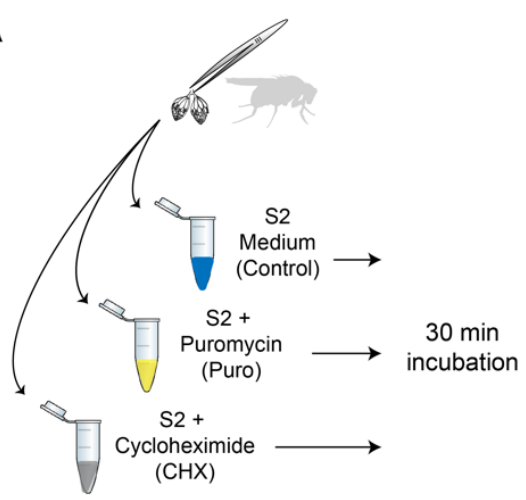

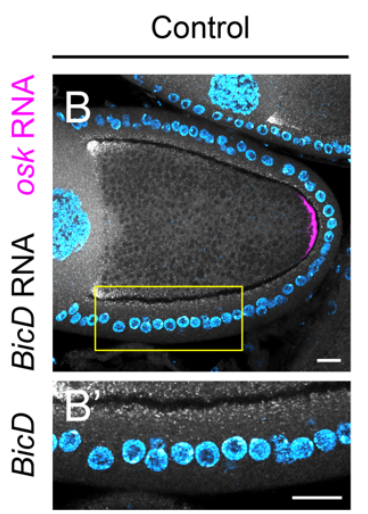
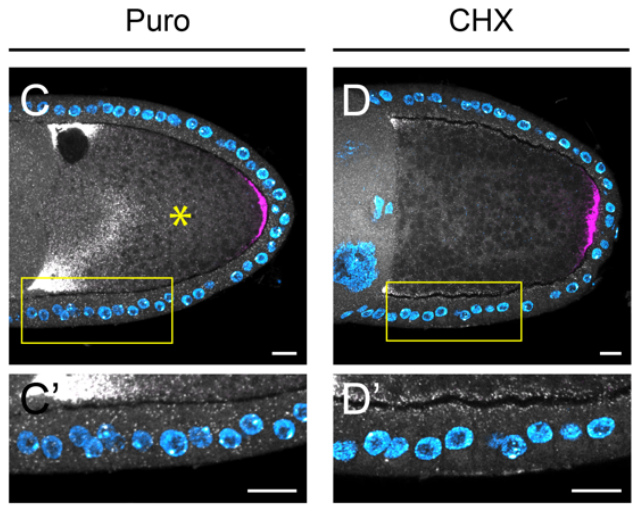
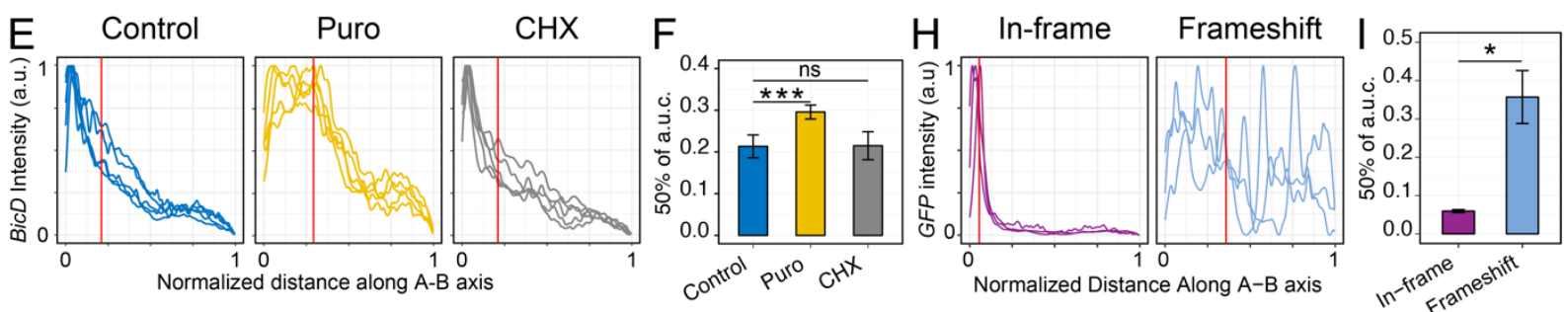

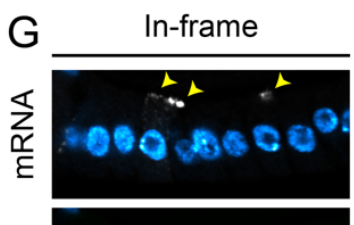

Frameshift

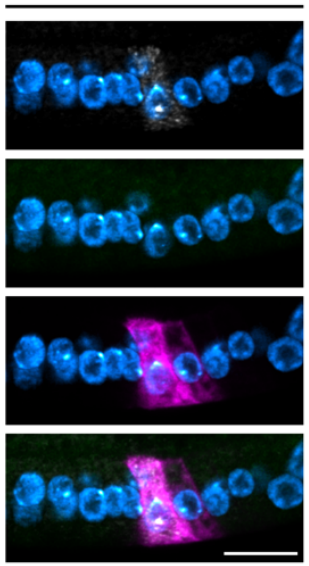

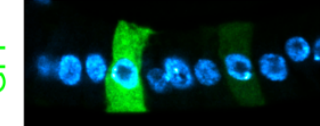
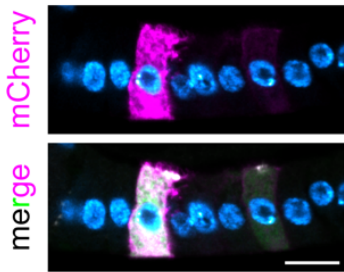
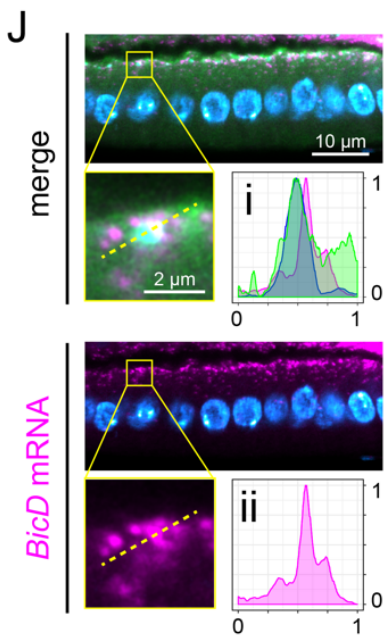
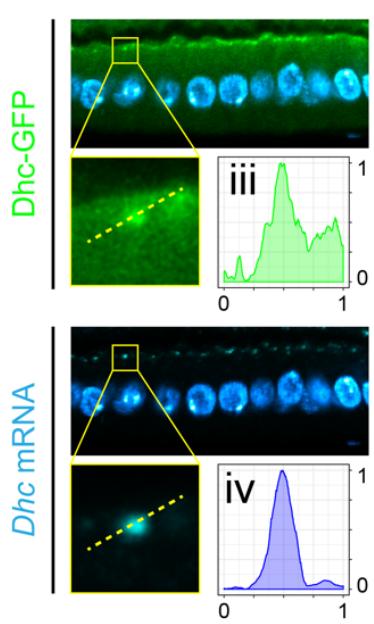
889 Figure 4. BicD RNA is co-translationally localized at cortical Dhc foci. A) Schematic

890 representation of the ex vivo treatment of wild-type ovaries with pharmacological inhibitors of

891 translation. B-D) Dual-color BicD (grayscale) and osk (magenta) smFISH experiments on Control (B-

892 B'), Puro- (C-C') or CHX-treated (D-D') ovaries. Insets show a magnification of the follicular epithelium

893 (bottom panels). Note the mislocalization of BicD RNA towards the center of the oocyte $\left(^{*}\right)$ in C). E)

894 Quantification of BicD RNA distribution along a linear ROI spanning the apical-basal axis of follicle

895 cells measured as smFISH fluorescence intensity in control (blue), Puro (yellow) and CHX (grey)

896 conditions. A red vertical line represents the mean $x$ value corresponding to the $50 \%$ of the cumulative

897 area under the curve (a.u.c.), a proxy for BicD degree of mislocalization. F) Statistical analysis of BicD

898 degree of mislocalization (mean a.u.c. \pm s.e.m) in each condition compared to control. Control-Puro:

$\left.899 \mathrm{p}=0.000879{ }^{(* *}\right)$; Control-CHX: $\mathrm{p}=0.9374$ (ns). G) Expression of different BicD-GFP constructs ("In-

900 frame": ${ }^{0} \mathrm{Bic}$-GFP; "Frameshift": ${ }^{(-1)} \mathrm{BicD}-\mathrm{GFP}$ or ${ }^{(+1)} \mathrm{Bic}$-GFP) in FC clones and analysis of

901 transgenic RNA distribution by smFISH with antisense GFP probes. Follicle cell clones expressing

902 each BicD-GFP construct are marked by CD8-mCherry (magenta). H) Quantification of In-frame

903 (purple) or Frameshift (light blue) BicD-GFP RNA distribution. I) Statistical analysis of BicD-GFP

904 degree of mislocalization (mean a.u.c. \pm s.e.m) in Frameshift compared to In-frame construct. $p=$

$9050.01719\left(^{*}\right)$. J) Localization of BicD RNA (magenta), Dhc RNA (cyan), and endogenously tagged Dhc-

906 GFP (green) in stage 10 follicular epithelium. Insets show a magnification of a single Dhc-GFP/Dhc

907 RNA focus. A dashed line indicates the cross-section along which each signal was measured (panels

908 i-iv). Signal intensities (y-axis) and line length (x-axis) were normalized in the 0-1 range. Nuclei (cyan)

909 are stained with DAPI. Scale bars $10 \mu \mathrm{m}$ unless otherwise specified. See also Figure S5 and Figure

910 S6.

911 
bioRxiv preprint doi: https://doi org/10.1101/2021.12 05.471303. this version posted December 7,2021 . The copyright holder for this

preprint (which was not certified by peer review) is the author/funder, who has granted bioRxiv a license to display the preprint in perpetuity. It is made available under aCC-BY-NC-ND 4.0 International license.

\section{$912 \quad$ Figure 5}

A

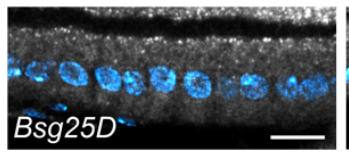

B
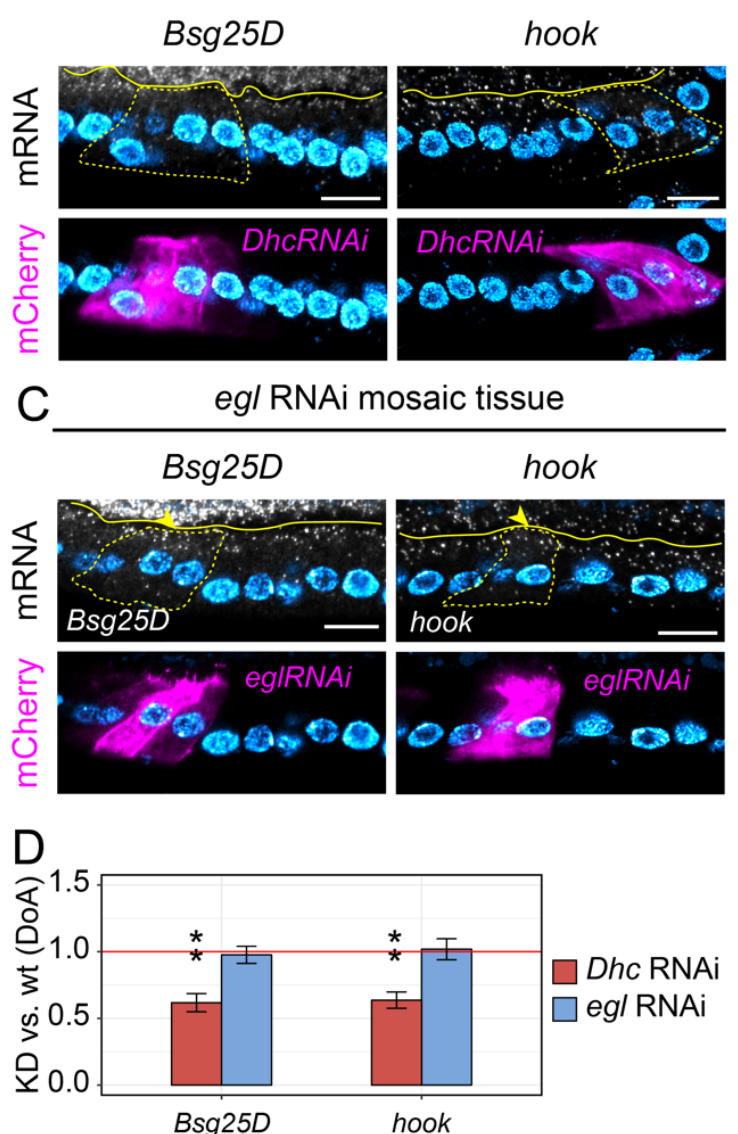

$\mathrm{H}$

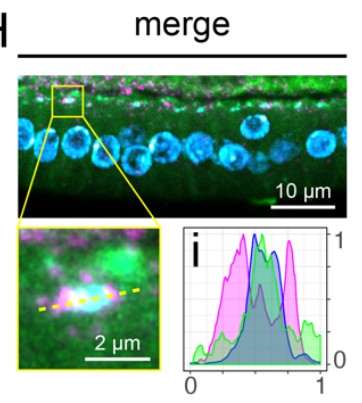

I
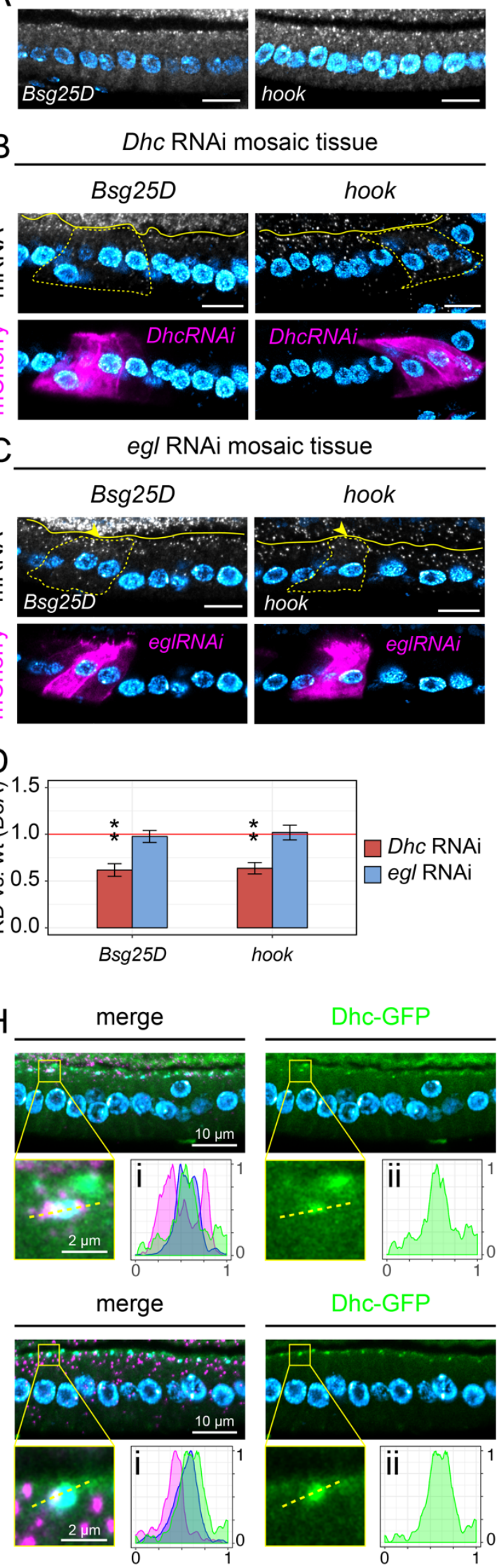

$\mathrm{E}$

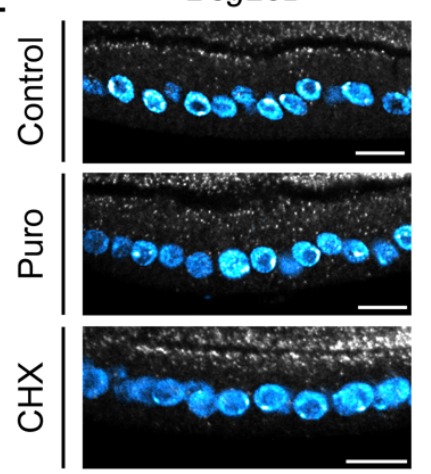

F
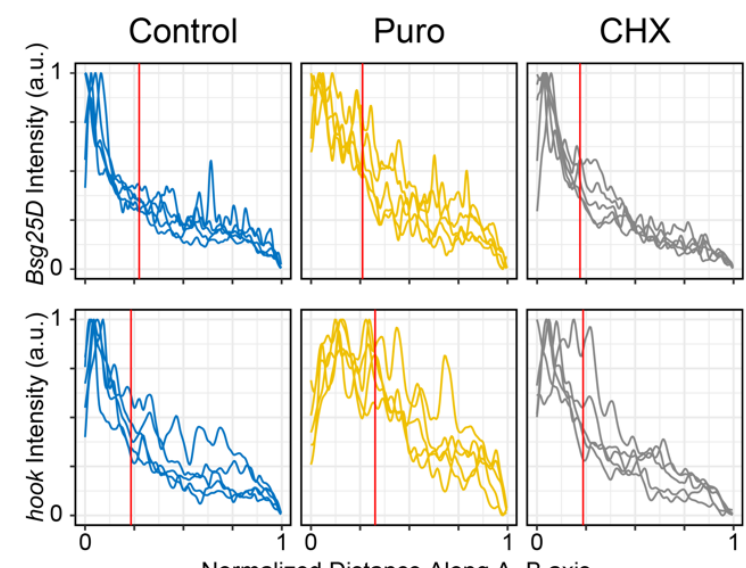

Normalized Distance Along A-B axis
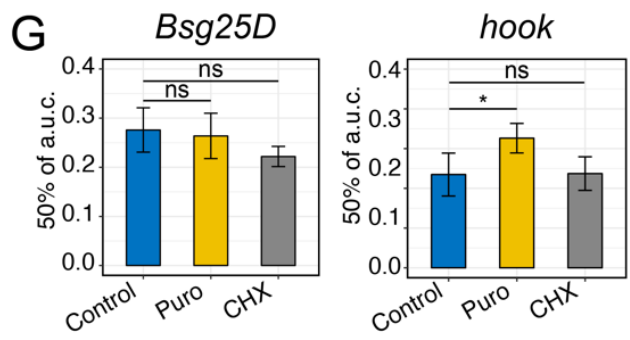

Bsg25D mRNA
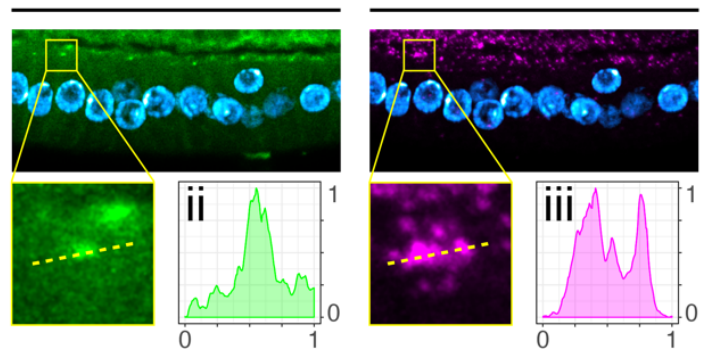

hook mRNA
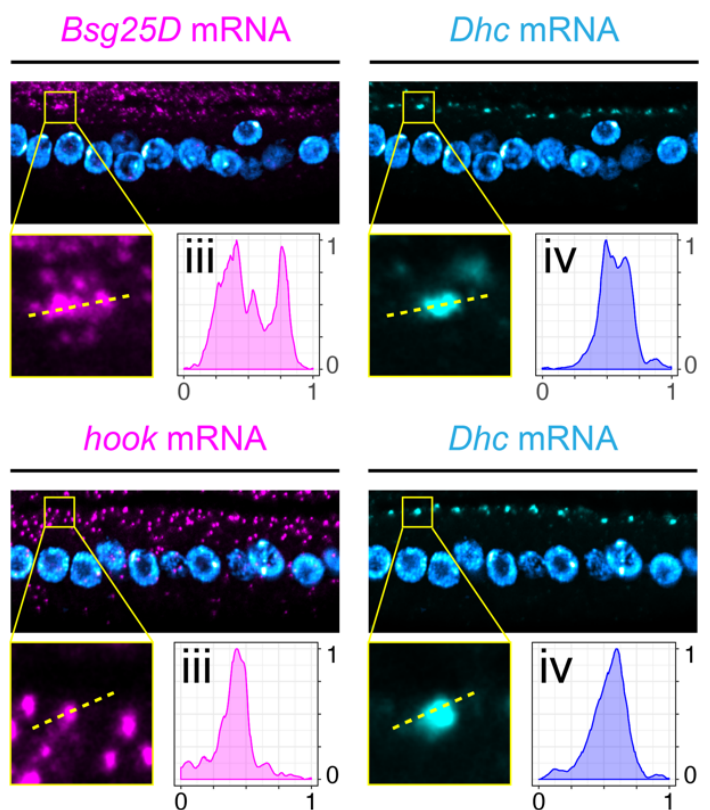

Dhe mRNA
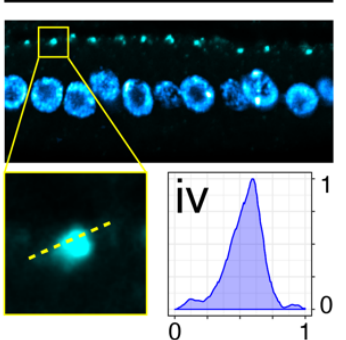
bioRxiv preprint doi: https://doi.org/10.1101/2021.12.05.471303; this version posted December 7, 2021. The copyright holder for this preprint (which was not certified by peer review) is the author/funder, who has granted bioRxiv a license to display the preprint in perpetuity. It is made available under aCC-BY-NC-ND 4.0 International license.

\section{Figure 5. The apical localization of hook and Bsg25D RNAs is mechanistically similar to BicD.}

915 A) Bsg25D and hook RNAs visualized by smFISH in wild-type FE. B-C) Localization of Bsg25D and

916 hook RNAs by smFISH in Dhc RNAi (B) and egl RNAi mosaic tissue (C). Mutant cells are marked by

917 the expression of CD8-mCherry (lower panels) and highlighted with a dashed line in smFISH images

918 (upper panels). Neighboring wild-type cells are unmarked. Arrowheads in C) indicate the persistence

919 of Bsg25D and hook RNAs apically in egl RNAi cells. A continuous yellow line demarcates the border

920 between the oocyte and the FE to facilitate the image interpretation. D) Quantification of changes in

921 the A-B distribution of Bsg25D and hook RNAs in conditions of downregulated dynein/BicD/Egl

922 transport. The $y$-axis shows the average values ( \pm s.e.m) of the KD/wt DoA for each RNA analyzed, in

923 each condition. The mean KD/wt DoA value for each RNA in each condition was tested against a

924 value of $\mathrm{KD} / \mathrm{wt}(\mathrm{DoA})=1$ (red horizontal line). Asterisks indicate mean values that significantly differ

925 from the reference value of $m u=1\left({ }^{*}=p<0.05 ;{ }^{* *}=p<0.01 ;{ }^{* * *}=p<0.001\right)$. E) Bsg25D (left panels) and

926 hook (right panels) RNA localization in the FE visualized by smFISH in Control, Puro- or CHX-treated

927 ovaries. E) Quantification of Bsg25D (upper panels) and hook (lower panels) RNA distribution along

928 linear ROIs spanning the apical-basal axis of follicle cells measured as smFISH fluorescence intensity

929 in control (blue), Puro (yellow) and CHX (grey) conditions. A red vertical line represents the mean $\mathrm{x}$

930 value corresponding to $50 \%$ of each area under the curve (a.u.c.). G) Statistical analysis of $B s g 25 D$

931 and hook degree of mislocalization (mean a.u.c. \pm s.e.m) in each condition compared to control.

932 Control-Puro(Bsg25D): $\mathrm{p}=0.6869$ (ns); Control-CHX(Bsg25D): $\mathrm{p}=0.05405$ (ns), Control-Puro(hook):

$933 p=0.01648\left(^{*}\right)$; Control-CHX(hook): $\mathrm{p}=0.9412(\mathrm{~ns})$. H-I) Localization of Bsg25D RNA (H) or hook RNA

934 (I) (magenta), Dhc RNA (cyan), and endogenously tagged Dhc-GFP (green) in stage 10 follicular

935 epithelium. Insets show a magnification of a single Dhc-GFP/Dhc RNA focus. A dashed line indicates

936 the cross-section along which each signal has been measured (panels i-iv). Signal intensities (y-axis)

937 and line length (x-axis) were normalized in the 0-1 range. Nuclei (cyan) are stained with DAPI. Scale

938 bars $10 \mu \mathrm{m}$ unless otherwise specified.

939 
bioRxiv preprint doi: https://doi.org/10.1101/2021.12.05.471303; this version posted December 7 2021. The copyright holder for this preprint (which was not certified by peer review) is the author/funder, who has granted bioRxiv a license to display the preprint in perpetuity. It is made available under aCC-BY-NC-ND 4.0 International license.

A

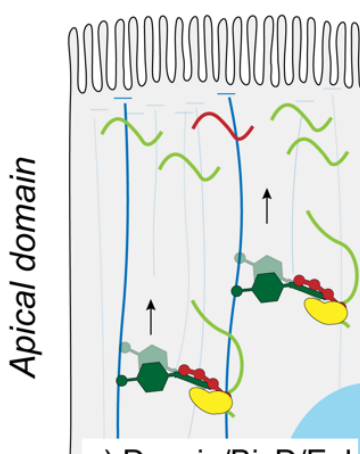

a) Dynein/BicD/Egl

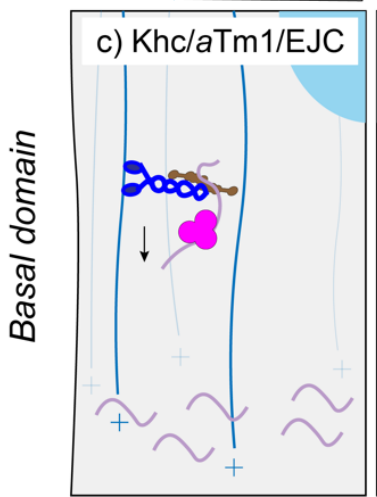

B

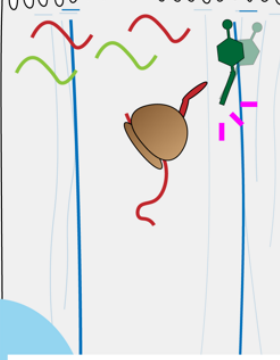

b) Co-translational

d) Dynein inhibition

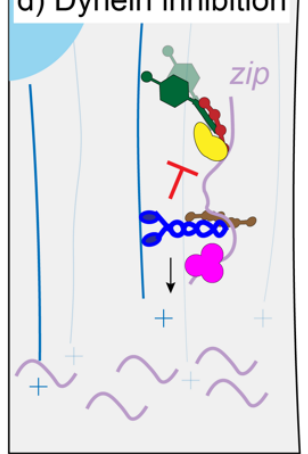

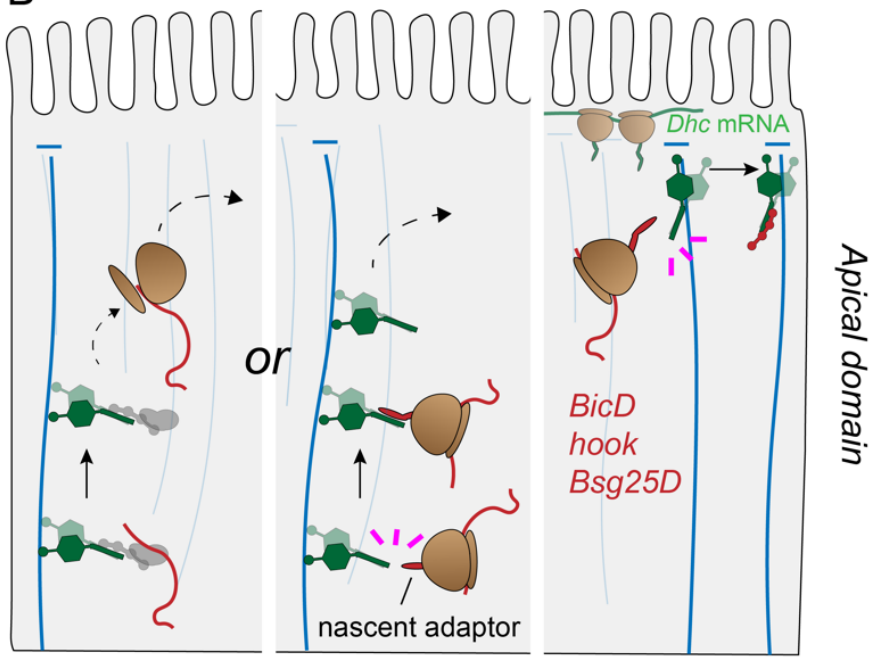

adaptor mRNA

20500. Khc/aTm1

dynein/BicD/Egl

unknown adaptor/RBP
EJC

文. ribosome 
bioRxiv preprint doi: https://doi org/10.1101/2021 12 05.471303. this version posted December 7, 2021. The copyright holder for this preprint (which was not certified by peer review) is the author/funder, who has granted bioRxiv a license to display the preprint in perpetuity. It is made available under aCC-BY-NC-ND 4.0 International license.

945 Figure 6. Models of RNA localization mechanisms in follicle cells. A) Model of the mechanism

946 underlying apical (a-b) and basal (c-d) RNA localization. Apical RNAs are localized at MT minus ends

947 by two dynein-dependent mechanisms: a) the dynein/BicD/Egl RNA transport machinery localizes

948 most of apical RNAs in the FE; b) a subset of dynein adaptors RNAs (BicD, Bsg25D, and hook)

949 localize co-translationally at cortical dynein foci. c) Basal RNAs are localized by Khc/aTm1/EJC

950 moving towards MT plus ends enriched basally. d) In the transport of basal RNAs, the dynein complex

951 is kept in an inhibited state by kinesin-1 and its regulators. B) Model for the apical localization of

952 adaptor RNAs. RNAs can reach the apical domain by either canonical RNA transport by an unknown

953 RBP complex or by interaction of the nascent adaptor protein with dynein/dynactin transporting the

954 translationally engaged RNA to the apical domain. Once at the apical cortex, the nascent adaptor

955 associates through its $\mathrm{N}$-terminal domain with newly translated cortically-anchored dynein, presumably

956 allowing the relief of both proteins' autoinhibition. 